\title{
Ethylenediurea (EDU) effects on hybrid larch saplings exposed to ambient or elevated ozone over three growing seasons
}

\author{
Evgenios Agathokleous ${ }^{1,2,3} \cdot$ Mitsutoshi Kitao $^{3} \cdot$ \\ Takayoshi Koike ${ }^{2,4}$
}

Received: 4 March 2021 / Accepted: 22 April 2021 / Published online: 25 May 2021

(C) The Author(s) 2021

\begin{abstract}
Ground-level ozone $\left(\mathrm{O}_{3}\right)$ pollution is a persistent environmental issue that can lead to adverse effects on trees and wood production, thus indicating a need for forestry interventions to mediate $\mathrm{O}_{3}$ effects. We treated hybrid larch (Larix gmelinii var. japonica $\times$ L. kaempferi) saplings grown in nutrient-poor soils with 0 or $400 \mathrm{mg}$ $\mathrm{L}^{-1}$ water solutions of the antiozonant ethylenediurea (EDU0, EDU400) and exposed them to ambient $\mathrm{O}_{3}$ (AOZ; 08:00 - 18:00 $\left.\approx 30 \mathrm{nmol} \mathrm{mol}^{-1}\right)$ or elevated $\mathrm{O}_{3}(\mathrm{EOZ}$; 08:00 - 18:00 $\approx 60 \mathrm{nmol} \mathrm{mol}^{-1}$ ) over three growing seasons. We found that EDU400 protected saplings against
\end{abstract}

Project funding: This research was partly supported by grant \#201802 of the Japan's Forestry and Forest Products Research Institute (FFPRI) and KAKENHI grant \#JP17F17102 of the Japan Society for the Promotion of Science (JSPS). E.A. acknowledges support from The Startup Foundation for Introducing Talent of Nanjing University of Information Science \& Technology (NUIST), Nanjing, China (Grant No. 003080).

The online version is available at http://www.springerlink.com

Corresponding editor: Yu Lei

Evgenios Agathokleous

evgenios@nuist.edu.cn

1 Key Laboratory of Agrometeorology of Jiangsu Province, School of Applied Meteorology, Nanjing University of Information Science and Technology (NUIST),

Nanjing 210044, People's Republic of China

2 Research Faculty of Agriculture, Hokkaido University, SapporoHokkaido 060-8589, Japan

3 Hokkaido Research Center, Forestry and Forest Products Research Institute (FFPRI), Sapporo 062-8516, Japan

4 Research Center for Eco-Environmental Science, Chinese Academy of Science, Beijing 100085, People's Republic of China most effects of EOZ, which included extensive visible foliar injury, premature senescence, decreased photosynthetic pigment contents and altered balance between pigments, suppressed gas exchange and biomass production, and impaired leaf litter decay. While EOZ had limited effects on plant growth (suppressed stem diameter), it decreased the total number of buds per plant, an effect that was not observed in the first growing season. These results indicate that responses to EOZ might have implications to plant competitiveness, in the long term, as a result of decreased potential for vegetative growth. However, when buds were standardized per unit of branches biomass, EOZ significantly increased the number of buds per unit of biomass, suggesting a potentially increased investment to bud development, in an effort to enhance growth potential and competitiveness in the next growing season. EDU400 minimized most of these effects of EOZ, significantly enhancing plant health under $\mathrm{O}_{3}$-induced stress. The effect of EDU was attributed mainly to a biochemical mode of action. Therefore, hybrid larch, which is superior to its parents, can be significantly improved by EDU under long-term elevated $\mathrm{O}_{3}$ exposure, providing a perspective for enhancing afforestation practices.

Keywords Air pollution - Ethylenediurea (EDU) . Hormesis · Plant protection · Tropospheric ozone $\left(\mathrm{o}_{3}\right)$. Larix gmelinii var. japonica $\times$ L. kaempferi

\section{Introduction}

Larches (Pinaceae), unlike the vast majority of conifers, are deciduous trees (Gower and Richards 1990; Givnish 2002; Osawa et al. 2010). They cover permafrost ecosystems in eastern Siberia (Osawa et al. 2010), and dominate nutrientpoor areas of the boreal zone and various high-latitude 
peatlands of the northern hemisphere (Givnish 2002). Their dominance in the latter habitat is often described as a paradox because evergreen vegetation would be anticipated to dominate (Givnish 2002). The advantage of larches over most other deciduous and evergreen trees can be partly explained by the higher nutrient retranslocation efficiency of larch (Matyssek 1986; Givnish 2002; Kitaoka et al. 2020) and advantageous water relations (Berg and Chapin 1994).

Owing to their unique ecophysiological characteristics, larches have a very wide distribution throughout the northern hemisphere (Givnish 2002; Usoltsev et al. 2002; Ryu et al. 2009). Larches are major trees for wood and biomass production in large regions of the northern hemisphere, thus being of considerable economic and environmental $\left(\mathrm{CO}_{2}\right.$ sink) value (Zhang et al. 2000; Usoltsev et al. 2002; Osawa et al. 2010; Kurinobu 2015; Ohta et al. 2019). Hence, important breeding programs targeted the improvement of larches by creating hybrids in Europe and Asia (Kurinobu 2015).

Japanese larch (Larix kaempferi (Lamb.) Carr.) has been a major afforestation species in northeast Asia, including Japan, since a long time ago (Ryu et al. 2009; Kurinobu 2015). However, it displays a number of disadvantages that can result in reduced growth and timber production, such as susceptibility to root rot and shoot blight diseases, deer and redback voles grazing, wind, and snow (Ryu et al. 2009; Kurinobu 2015). Therefore, long-lasting breeding programs have led to a new hybrid $\left(\mathrm{F}_{1}\right)$ with improved characteristics (Kurinobu 2015). This hybrid between Dahurian larch $(L$. gmelinii var. japonica) and Japanese larch (L. kaempferi) was found to be promising and planted widely in northern Japan (Ryu et al. 2009; Kurinobu 2015). Seedlings of hybrid larch are planted into natural soils in the field for afforestation, without any fertilization. However, while hybrid larch displays heterosis under various environmental conditions, it appears to be susceptible to ground-level ozone $\left(\mathrm{O}_{3}\right)$ (Sugai et al. 2018; Wang et al. 2018).

Ozone concentrations are elevated throughout the globe, relative to the pre-industrial concentrations, and $\mathrm{O}_{3}$ is one of the most puzzling-to-control air pollutants nowadays $(\mathrm{Xu}$ et al. 2020; Gao et al. 2020; Diaz et al. 2020). Current ambient $\mathrm{O}_{3}$ concentrations are potentially toxic for agricultural crops, trees/shrubs, and other types of vegetation in many areas of the northern hemisphere (Singh et al. 2018; Käffer et al. 2019; Sicard et al. 2020; Proietti et al. 2020; Mukherjee et al. 2021), especially in the Asian region (Koike et al. 2013; Izuta 2017). Ozone is taken up by plants during gas exchange with the atmosphere via stomata, thus generating the production of harmful chemical species and activating stress defense mechanisms (Cieslik et al. 2009; Kitao et al. 2015; Moura et al. 2018; Bellini and De Tullio 2019; Kinose et al. 2020; Xu et al. 2021). These responses lead to inhibitory effects above taxon-specific stress thresholds, including inhibition of photosynthesis and photosynthates translocation, growth, yields, and productivity (Fiscus et al. 2005; Matyssek et al. 2010). Ozone pollution can affect a multitude of ecological processes and functions (Ueno et al. 2016, 2020; Fuhrer et al. 2016; Yue et al. 2017; Unger et al. 2020; Blande 2021), as well as reduce the yields of agricultural crops (Mills et al. 2018; Feng et al. 2019a and 2020; Hu et al. 2020). Moreover, $\mathrm{O}_{3}$ pollution can significantly reduce annual wood production (Sacchelli et al. 2021), creating a need to protect trees that are important for wood production.

Ethylenediurea (EDU) is a synthetic chemical that was reported to protect bean plants from $\mathrm{O}_{3}$ injury in the 1970 s, and has been extensively studied for its phytoprotective mode against $\mathrm{O}_{3}$ injury since then (Manning et al. 2011; Singh et al. 2015; Agathokleous 2017; Tiwari 2017). Although EDU improves various physiological, biochemical, growth, and productivity traits of plants under $\mathrm{O}_{3}$ stress in the framework of hormesis, there is high intraspecific variation and no universal mechanism explaining its phytoprotective mode of action (Feng et al. 2010; Oksanen et al. 2013; Singh et al. 2015; Agathokleous 2017; Tiwari 2017; Ashrafuzzaman et al. 2018; Pandey et al. 2019; Surabhi et al. 2020). Besides, EDU studies concerning tree species are few (Paoletti et al. 2009; Feng et al. 2010; Agathokleous 2017; Giovannelli et al. 2019) relative to EDU studies concerning non-tree species. Importantly, there have been only two research programs studying the efficacy of EDU in protecting tree species over several years; one with poplars and one with Japanese larch (Giovannelli et al. 2019; Agathokleous et al. 2021). Therefore, the effects of EDU on plants under $\mathrm{O}_{3}$ stress over several years remain largely unexplored, yet it is essential to confirm whether EDU can protect various trees against $\mathrm{O}_{3}$ for multiple years, indicating that long-term responses should be evaluated.

In the framework of a previous study, two independent experiments were performed to study $\mathrm{EDU}-\mathrm{O}_{3}$ effects on Japanese larch (hybrid larch's pollen father), showing that EDU significantly protected Japanese larch plants against $\mathrm{O}_{3}$-induced phytotoxicty (Agathokleous et al. 2021). In the first experiment, the response of seedlings (size and biomass) to increasing doses of EDU was studied in a free-air $\mathrm{O}_{3}$-concentration enrichment (FACE) system, by exposing seedlings to ambient or elevated $\mathrm{O}_{3}$ for one growing season. In the second experiment, saplings were treated with EDU while exposed to only ambient $\mathrm{O}_{3}$ in two growing seasons and only elevated $\mathrm{O}_{3}$ in the following two growing seasons, and their size and biomass were studied (Agathokleous et al. 2021). In the present study, we evaluated the effects of EDU ( 0 or $400 \mathrm{mg} \mathrm{L}^{-1}$ ) on hybrid larch saplings exposed to either ambient or elevated $\mathrm{O}_{3}$ for three growing seasons using a contemporary FACE facility. An advantage of this experiment, compared to the vast majority of studies on $\mathrm{O}_{3}$ effects on plants, is that a non-fertilized soil was used to create near real-world conditions. Several traits of 
gas exchange, photosynthetic pigments, growth, and biomass were studied, as well as litter decomposition. We hypothesized that elevated $\mathrm{O}_{3}$ would negatively affect gas exchange and photosynthetic pigments, thus also inhibiting growth and biomass production, effects that EDU can alleviate (Feng et al. 2010; Oksanen et al. 2013; Singh et al. 2015; Agathokleous 2017; Tiwari 2017). Because of the decreased energy reservoirs under severe $\mathrm{O}_{3}$ stress, we hypothesized that plants may show altered allocation of resources toward buds, which define next year (future) re-growth, and became interested in whether EDU can protect against such effects. As elevated $\mathrm{O}_{3}$ decreases foliage quality, especially causing visible injuries on the leaves (e.g., necrosis, chlorosis, or discoloration), we also hypothesized that such low-quality leaf litter may lead to changes in litter decay, and that EDU may protect against such $\mathrm{O}_{3}$-induced effects by protecting leaves against $\mathrm{O}_{3}$ toxicity. Elevated $\mathrm{O}_{3}$ can also impair leaf $\mathrm{N}$ resorption (Shang et al. 2018), which may affect litter decay rate and plant growth in long-term. For example, if the decay rate of potentially $\mathrm{N}$-enriched litter is faster in elevated $\mathrm{O}_{3}$ than in ambient $\mathrm{O}_{3}$, potentially inhibited plant growth due to impaired leaf $\mathrm{N}$ resorption might be alleviated to some extent. By showing that EDU can significantly improve hybrid larch seedlings under $\mathrm{O}_{3}$ stress, this study offers a perspective to enhance the success of afforestation with hybrid larch by preconditioning plants to $\mathrm{O}_{3}$ via the exogenous application of EDU. This experiment differs from the previous experiments with larches exposed to EDU-O (Agathokleous et al. 2021) in that this experiment includes (1) hybrid larch, (2) both ambient and elevated $\mathrm{O}_{3}$ treatments in three growing seasons, and (3) assessment of physiological mechanisms as well as growth over time.

\section{Materials and methods}

\section{Experimental site}

The experiment was conducted at the Sapporo Experimental Forest $\left(43^{\circ} 0^{\prime} \mathrm{N}, 141^{\circ} 2^{\prime}\right.$ E, $15 \mathrm{~m}$ a.s.l.) of the Field Science Center of Northern Biosphere (FSC) of Hokkaido University, Sapporo, Japan, in three growing seasons (2014-2016). In this area the snow-free season commonly spans from late April to mid-November. Data of meteorological parameters were logged by a nearby monitoring station $\left(43^{\circ} 03.6^{\prime} \mathrm{N}\right.$, $141^{\circ} 19.7^{\prime}$ E) operated by the Japan Meteorological Agency (http://www.jma.go.jp/jma/indexe.html). The average values $( \pm$ indicates standard deviation for environmental data and standard error for experimental/statistical results hereafter) of the main parameters were calculated for the months April-October of 2014, 2015, and 2016. The monthly average, daily maximum, and daily minimum air temperature was $16.2 \pm 5.2,20.8 \pm 5.1$, and $12.5 \pm 5.6{ }^{\circ} \mathrm{C}$, respectively, while the wind speed was $3.69 \pm 0.53 \mathrm{~m} \mathrm{~s}^{-1}$. The relative humidity, monthly total sunshine duration, and monthly precipitation were $67 \% \pm 7 \%, 1877 \pm 37 \mathrm{~h}$, and $106 \pm 63 \mathrm{~mm}$, respectively.

\section{Plant material}

Hybrid larch two-year-old saplings were stored in dark under low temperature, at the nursery of Forestry Research Institute, Hokkaido Research Organization, Bibai (near Sapporo), Japan. Forty-eight uniform saplings were selected and transported to the campus of Hokkaido University in Sapporo, on May 15, 2014, and kept in an incubator at a constant temperature of $3 \pm 0.5^{\circ} \mathrm{C}$ under light. The saplings were planted in $15-\mathrm{L}$ pots on June 5, 2014. The pots contained an 1: 1 mixture of two commercial soils $(\mathrm{pH}=5.92 \pm 0.02)$, viz. well-weathered volcanic ash Akadama soil and Kanuma pumice soil (DCM Homac CO., LTD., Sapporo, JP), which contain no organic matter and are poor in nutrients (Agathokleous et al. 2016a). Soils are originated from Kanuma town of Tochigi prefecture, central Japan. Both soils are originated from volcanic ash (a kind of Vitric Andosols), and are deficient in phosphorus and poor in nitrogen, and commonly occur in Hokkaido (Schmincke 2004). The major composition of the soil substrates used, according to the manufacturer, is: $58.6 \% \mathrm{SiO}_{2}, 17.1 \% \mathrm{Al}_{2} \mathrm{O}_{3}, 1.93 \% \mathrm{Fe}_{2} \mathrm{O}_{3}$, $0.076 \% \mathrm{MgO}, 0.044 \% \mathrm{CaO}$, and $0.041 \% \mathrm{MnO}$ for Kanuma, and $39.5 \% \mathrm{SiO}_{2}, 24.6 \% \mathrm{Al}_{2} \mathrm{O}_{3}, 9.0 \% \mathrm{Fe}_{2} \mathrm{O}_{3}, 2.2 \% \mathrm{MgO}$, $0.88 \% \mathrm{CaO}$, and $0.14 \% \mathrm{MnO}$ for Pumice.

The pots were placed under ambient conditions at a sunlight-exposed ambient site of the experimental nursery of the FSC. A fully randomized design was employed, with a pot-to-pot distance of $30 \mathrm{~cm}$. At planting, the average values of height and fresh weight were $13.8 \pm 0.4 \mathrm{~cm}$ and $1.7 \pm 0.1 \mathrm{~g}$. The average diameter at the base, middle, and uppermost part of the stem was $2.0 \pm 0.06,1.5 \pm 0.04$, and $1.2 \pm 0.03 \mathrm{~mm}$, respectively. The saplings had on average $16.8 \pm 0.5$ buds and $20.2 \pm 1.5$ needles. The diameter was assessed with a digital caliper with an accuracy of $0.01 \mathrm{~mm}$, while the height was evaluated using a measuring tape with a 1-mm gradient. The fresh weight was measured after roots were immersed in deionized water so to have uniform amount of humidity across saplings.

On 6 June, 2014, the pots were transferred into the FACE plots. Eight randomly selected saplings were placed at the south side of each FACE plot (the schematic diagram of the plots was presented elsewhere (Agathokleous et al. 2021), and all plots remained under ambient conditions until the $\mathrm{O}_{3}$ treatment began. Henceforth, and in each growing season, the pots position in each FACE plot was re-adjusted biweekly to minimize edge effects. Furthermore, the saplings of each $\mathrm{O}_{3}$ treatment were rotated across the three FACE plots with same $\mathrm{O}_{3}$ treatment bimonthly. 
Apart from the EDU and $\mathrm{O}_{3}$ treatments, plants were not treated with any other means. Therefore, plants were also rain-fed. However, on 20 May, 2016, $950 \mathrm{~mL}$ of tap water were given to each plant due to unusual increases of temperature during those days $\left(>25^{\circ} \mathrm{C}\right)$. Furthermore, $400 \mathrm{~mL}$ of water were given to each plant the night before gas exchange measurements.

\section{EDU treatments}

Saplings were treated with soil drench containing either 0 or $400 \mathrm{mg} \mathrm{EDU} \mathrm{L}^{-1}$ (200 $\mathrm{mL}$ per pot per application). The concentration of $400 \mathrm{mg} \mathrm{L}^{-1}$ was selected as the upper limit of the range of EDU concentrations offering sufficient phytoprotection from $\mathrm{O}_{3}$ toxicity based on the broad literature (Feng et al. 2010; Agathokleous 2017). This concentration also effectively protected Japanese larch (hybrid larch parent) seedlings and saplings against $\mathrm{O}_{3}$ phytotoxicity (Agathokleous et al. 2021). Before applying EDU in 2014, half of the saplings in each FACE plot were assigned the one EDU treatment and the other half were assigned the other EDU treatment; the assignment was random. Henceforth, each sapling was receiving the same EDU treatment every 9 days during the growing seasons of 2014, 2015, and 2016. EDU was first applied on July 29, April 14, and April 24 of 2014, 2015, and 2016, respectively, and repeated 12, 22, and 17 times in each of the growing seasons. Hence, each sapling was treated with EDU 51 times in total, equalling to $10.2 \mathrm{~L}$ of water solution. The 9-day application interval was selected considering the known effective persistence of EDU in the leaf apoplast, and based on the widely successful results that EDU produced in the literature (Paoletti et al. 2009; Agathokleous 2017). There were 4 saplings per EDU treatment per FACE plot, i.e., 12 saplings per EDU treatment per $\mathrm{O}_{3}$ treatment.

\section{Ozone treatments}

For $\mathrm{O}_{3}$ treatments, the FACE system with tree communities of the FSC was used, which consists of 6 plots scattered around the experimental forest. Details of the technical characteristics of this system can be found in supplemental materials published along with a recent article (Agathokleous et al. 2021). Three plots represented ambient $\mathrm{O}_{3}$ (AOZ) treatment, while the other three represented elevated $\mathrm{O}_{3}$ (EOZ) treatment. EOZ plots were enriched with additional $\mathrm{O}_{3}$ during the daytime (07:00 - 17:00, Japan Standard Time, JST) to reach target elevated $\mathrm{O}_{3}$ exposures. EOZ treatment was active from August 15 to October 26, 2014, from April 24 to October 26, 2015, and from May 19 to October 1, 2016. When EOZ plots enrichment with $\mathrm{O}_{3}$ was inactive, plants in the plots were exposed to ambient $\mathrm{O}_{3}$ concentrations. Ambient $\mathrm{O}_{3}$ concentrations were logged every $1 \mathrm{~min}$
(TUV-1100; Tokyo Industries Inc. Tokyo, Japan). The mean daily 10-h (08:00 - 18:00 Japan Standard Time, JST) ambient $\mathrm{O}_{3}$ mixing ratio was $22.3 \pm 3.3,34.3 \pm 5.5$, and $32.3 \pm 5.7 \mathrm{nmol} \mathrm{mol}^{-1}$ in the growing seasons of 2014, 2015, and 2016, respectively. The mean $10-\mathrm{h} \mathrm{O}_{3}$ concentrations in the EOZ plots were $60.1,72.1$, and $55.8 \mathrm{nmol} \mathrm{mol}^{-1}$ in the growing seasons of 2014, 2015, and 2016, respectively. Further details about $\mathrm{O}_{3}$ exposure were presented in earlier publications (Agathokleous et al. 2017, 2021).

\section{Treatments effect assessment}

\section{Growth}

Growth of plants was monitored through time. Plant height, crown span (from two farthest points of the crown), stem basal diameter (average of two crosswise measurements per plant), and total number of buds per plant were measured. Plant height and crown span were measured $(\mathrm{cm})$ with a measuring tape with an accuracy of $1 \mathrm{~mm}$. Stem diameter was measured (mm; 2-decimals accuracy) with a digital caliber. Plant height, crown span, stem diameter, and number of buds of all plants were measured before the beginning of treatments (7/29/2014). Then, plant height (10/30/2014, 4/13/2015, 6/11/2015, 7/14/2015, 8/22/2015, 10/6/2015, $10 / 2 / 2016)$ and crown span $(10 / 30 / 2014,4 / 13 / 2015$, 6/11/2015, 7/14/2015, 8/22/2015, 10/6/2015, 10/2/2016) were measured 7 times post-treatment. Stem diameter was measured 5 times (10/30/2014, 4/13/2015, 7/14/2015, $10 / 6 / 2015,10 / 2 / 2016$ ), while number of buds was measured 2 times post-treatment (4/13/2015, 10/2/2016).

\section{Photosynthetic pigments}

Photosynthetic pigments were measured in sun-lit needles collected on October 31, 2014, and July 25, 2015, and September 2, 2015. This taxon has dimorphic shoots/branches, with single needles and several buds on long shoots and dense clusters of needles $(20-50)$ and a single bud on short shoots, and the normal needle senescence of the experimental plants began in November.

Some needles, usually single needles on long shoots, are not shed and overwinter, especially during the seedling stage (Kurahashi 1988), thus helping plant regrowth in the following spring-summer. For the first assessment (2014), single needles on the main shoot (stem) were analyzed to examine potential influence to be carried over in the next growing season. For the second and third assessments (2015), mature needles from dense clusters of needles on short shoots were analyzed to examine the effect in the current growing season. The sampling of July (2015) was conducted during the peak of the growing season, when severe $\mathrm{O}_{3}$ visible injury existed in the plants treated with EDU0 and EOZ (it 
appeared from early June); no such visible injury existed in plants treated with EDU400 and EOZ (Fig. 1). During the September (2015) sampling, however, the severely injured needles of plants treated with EDU0 and EOZ had already been shed prematurely. Therefore, the sampling conducted in September (2015) concerns less-affected needles, in terms of $\mathrm{O}_{3}$-induced visible injury. Plant senescence was recorded after careful visual observation of each plant and its surrounding soil surface. All the plants were observed, and binary data were collected (yes or no) to calculate how many plants per treatment were (prematurely) senescing. There was no defoliation induced by any other factor over the course of the experiment.

For each plant, needles were put in $4 \mathrm{~mL}$ of DMSO and placed in an incubator at $65{ }^{\circ} \mathrm{C}$ for $4 \mathrm{~h}$, while shaking from time to time (Shinano et al. 1996). Before inserting them into DMSO, the needles were scanned (Canon LIDE 40, Tokyo), and the area of the tissue (single-side projection) was measured using the LAI32 v.0.377 software (@) Kazukiyo Yamamoto). Extracts were evaluated (GeneSpec III; Hitachi Genetic Systems; MiraiBio, Alameda, CA) immediately after incubation, and the absorbance was recorded at the optical densities of 470, 543, 648, and $665 \mathrm{~nm}$. The values at 543 and $470 \mathrm{~nm}$ were used to assess carotenoids, according to the method of Lichtenthaler 1987. The values at 648 and $665 \mathrm{~nm}$ were used to assess chlorophyll $a$, chlorophyll $b$, and total chlorophylls (chlorophyll $a+b$ ), according to a previously described method (Barnes et al. 1992; Shinano et al. 1996). The ratios of chlorophyll $a$ to chlorophyll $b$ and carotenoids to total chlorophylls were also calculated.

\section{Gas exchange}

Gas exchange was measured in sun-lit needles on clear days between June 23 and 30, 2015 (all plants were measured). Mature needles of long-shoot were selected randomly; $\mathrm{O}_{3}$-symptomatic needles of random $\mathrm{O}_{3}$-injury degree were collected from EOZ. A soil drench of $400 \mathrm{~mL}$ water was given to each seedling the evening before the measurements.
The needles were adapted to the chamber for 20 min before starting the A/Ci curve program. After photosynthesis measurements, the measured needles were sampled for area estimation. Gas exchange was recorded with different LiCor instruments (LI-6400, Li-Cor Inc., Lincoln, NE, USA) measuring simultaneously. Plants of different experimental conditions were rotated between LiCor instruments and over time. Net photosynthetic rate $\left(A_{380}\right)$, stomatal conductance $\left(g s_{380}\right)$, and transpiration rate $\left(E_{380}\right)$ were measured at ambient $\mathrm{CO}_{2}$ $\left(380 \mu \mathrm{mol} \mathrm{mol}^{-1}\right), 55 \%-65 \%$ relative air humidity, $25{ }^{\circ} \mathrm{C}$ leaf temperature, and a light saturated photosynthetic active photon flux (PDF) of $1500 \mu \mathrm{mol} \mathrm{m} \mathrm{m}^{-2} \mathrm{~s}^{-1}$ (Koike et al. 2012). The $\mathrm{A} / \mathrm{Ci}$ curve (the curve between net $\mathrm{CO}_{2}$ assimilation rate and intercellular $\mathrm{CO}_{2}$ concentration) was developed using fluctuating $\mathrm{CO}_{2}$ levels (12 levels) in the leaf chamber fluorometer, with constant PDF, relative humidity, and temperature. The LI-6400 AutoProgram was used. Based on the A/ Ci curve and using a C3 plant biochemical model (Farquhar et al. 1980; Long and Bernacchi 2003), net photosynthetic rate at saturated $\mathrm{CO}_{2}$ of $1500 \mu \mathrm{mol} \mathrm{CO}{ }_{2} \mathrm{~mol}^{-1}\left(A_{\max }\right)$, maximum rate of carboxylation $\left(V c_{\max }\right)$, and maximum rate of electron transport rate $\left(J_{\max }\right)$ were estimated. Gas exchange measurements were conducted during morning hours (completed by noon).

\section{Litter decay}

On 10 October, 2015, mesh was installed on each pot to collect the leaf litter; senescence had not started yet (or restarted for EOZ plants that had premature senescence earlier; see Results). Leaf litter was collected from each plant on October 19, 2015, put in air-dry oven for $48 \mathrm{~h}\left(65^{\circ} \mathrm{C}\right)$, and stored in zip-lock bags at room temperature and dark conditions until further use in the next snow-free season. In September 2016, collected needles of all plants of each treatment were pooled and mixed to give a pool of fallen needles for each treatment $(\mathrm{AOZ} \times \mathrm{EDU} 0, \mathrm{AOZ} \times \mathrm{EDU} 400, \mathrm{EOZ} \times \mathrm{EDU} 0$, and $\mathrm{EOZ} \times \mathrm{EDU} 400$ ). From this pool of fallen needles, random samples were taken in order to prepare 12 samples per

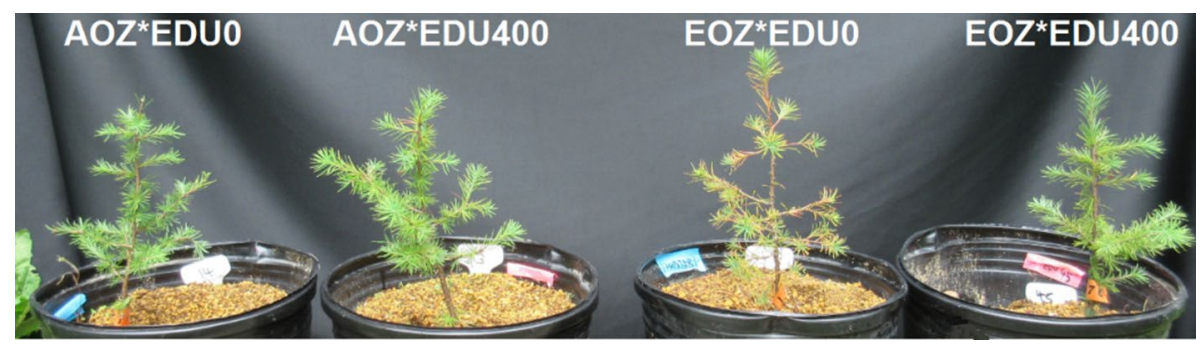

Fig. 1 Ozone-induced visible injury in hybrid larch plants grown in ambient ozone (AOZ) or elevated ozone (EOZ) and treated with $0 \mathrm{mg} \mathrm{L}^{-1}$ (EDU0) or $400 \mathrm{mg} \mathrm{L}^{-1}$ (EDU400) ethylenediurea (EDU) over three growing seasons. This observation took place in July,
2015 (second growing season). No ozone-induced visible injury was observed in plants grown in $\mathrm{AOZ}$ or in $\mathrm{EOZ}$ and treated with EDU400 
treatment. A customized plastic mesh bag of standardized size, which was same for all bags, was prepared for each sample. A standardized amount of needles was added in each litter bag, and the bag was closed using stainless steel staples. While authors remember that the initial amount of needles was standardized to $1.5 \mathrm{~g}$, no record of this value could be found in the experimental notes. However, only the relative difference among treatments was of interest in this study. On September 7, 2016, the prepared litter bags were implanted in soil ( $8 \mathrm{~cm}$ depth). Four experimental plots were established, scattered across the experimental forest, under ambient conditions. Three litter bags of each treatment were implanted in each plot, with a distance of $20 \mathrm{~cm} \times 20 \mathrm{~cm}$ between litter bags. The experimental design was fully randomized in each plot. Tea bags were retrieved from all the plots 74 days after the implanting (20 November), i.e., at the end of the snow-free period. The needles of each tea bag were dried in an oven $\left(60^{\circ} \mathrm{C}\right)$ to constant mass, and the mass was measured.

\section{Biomass}

At the end of the experiment, all plants were harvested (October 2, 2016). Each root system was retrieved as an intact unit (no root losses), followed by removal of soil particles and alien roots by hand and gently washing with tap water. Each organ (root, needles, and stem + branches) was dried in an oven to constant mass at $60{ }^{\circ} \mathrm{C}$, and the shoot (needles + stem + branches) and total plant (shoot + root) dry mass was calculated. The ratio of root mass to shoot mass $(\mathrm{R} / \mathrm{S})$ was also calculated.

\section{Data analyses}

The threshold of statistical significance for all the tests was set a priori to an alpha level of 0.05 . Because some of the data distributions did not follow a Gaussian pattern, the data of each response variable were transformed with a Box-Cox power transformation, following a method described previously (Agathokleous et al. 2016b). While photosynthetic pigments were evaluated three times in total, a dependentsample design with time being within effects factor was not employed because measurements were conducted with different kinds of needles from different years. Therefore, data of photosynthetic pigments, gas exchange, biomass (and ratio of total number of buds per plant at harvest to branches dry mass at harvest), and litter mass following retrieval from soil were analyzed with a General Linear Model (GLM) adjusted with Method I Sum of Squares of Overall and Spiegel (Overall and Spiegel 1969; Howell and Mcconaughy 1982). Ozone and EDU were fixed factors and plot was random factor. This "stepdown analysis" is ideal for balanced analyses of variance (equal $n$, orthogonal), and the specification of the effects follows a proper hierarchical order in the model statement. Growth traits were analyzed with a three-factor GLM, with time within-effects factor and $\mathrm{O}_{3}$ and EDU between-effects factors. Time factor had 8, 8, 6 , and 3 levels for plant height, crown span, stem diameter, and number of buds, respectively. Posthoc multiple comparisons, where needed, were examined with Bonferroni test. We also calculated the Cohen's delta $(\delta)$ for AOZ-EDU0 versus EOZ-EDU0 for both the number of buds and the biomass of branches per plant, as described by Agathokleous et al. (2016b). Processing of data and statistical analyses were done with EXCEL 2010 (Microsoft, Redmond, CA, USA) and STATISTICA (v.10, StatSoft, Tulsa, OK, USA).

\section{Results}

\section{Visible foliar injury}

Visible foliar injury was monitored in the second growing season (2015), in which almost all physiological measurements were also conducted. Premature senescence occurred in $33.3 \%$ of the EOZ $\times$ EDU0 plants in early June; none of the plants of other treatments exhibited senescence at this point. At this point of time, all the EOZ $\times \mathrm{EDU} 0$ plants exhibited $\mathrm{O}_{3}$-induced visible foliar injury (e.g., Fig. 1), affecting on average $28.3 \% \pm 6.5 \%$ of the foliage, and the injury was low to moderate. Conversely, $50 \%$ of the EOZ $\times$ EDU400 plants exhibited $\mathrm{O}_{3}$-induced visible foliar injury, and the injury was negligible, affecting only on average $1.0 \% \pm 0.4 \%$ of the foliage. Premature senescence of the few needles of these EOZ $\times$ EDU400 plants began in early July. At this point of time, on average $2.8 \% \pm 0.9 \%$ and $48.4 \% \pm 10.0 \%$ of the foliage of EOZ $\times$ EDU 400 and EOZ $\times$ EDU0 plants was injured (Fig. 1). By August 28, the premature senescence had stopped in $\mathrm{O}_{3}$-injured plants because injured needles had already been shed; the normal senescence in other plants had not started before mid. October. $\mathrm{No}_{3}$-induced visible injury was observed in $\mathrm{AOZ}$ plants throughout the experiment.

\section{Leaf photosynthetic pigments}

In October, 2014, $\mathrm{O}_{3}$ was not a significant main factor for any of the photosynthetic pigment traits (Figs. 2a-d, 3a-b). EDU was a marginally significant main factor for chlorophyll $b$ (Fig. 2b), chlorophyll $a+b$ (Fig. 2c), and chlorophyll $a$ to $b$ ratio (Fig. 3a). In particular, saplings treated with EDU400 had $43.9 \%$ and $32.0 \%$ higher chlorophyll $b$ (Fig. 2b) and chlorophyll $a+b$ (Fig. 2c) content, and 39.0\% lower chlorophyll $a-b$ ratio than plants treated with EDU0. Similarly, the $\mathrm{O}_{3} \times$ EDU interaction was significant for chlorophyll $b$ (Fig. 2b), chlorophyll $a+b$ (Fig. 2c), and chlorophyll $a-b$ 

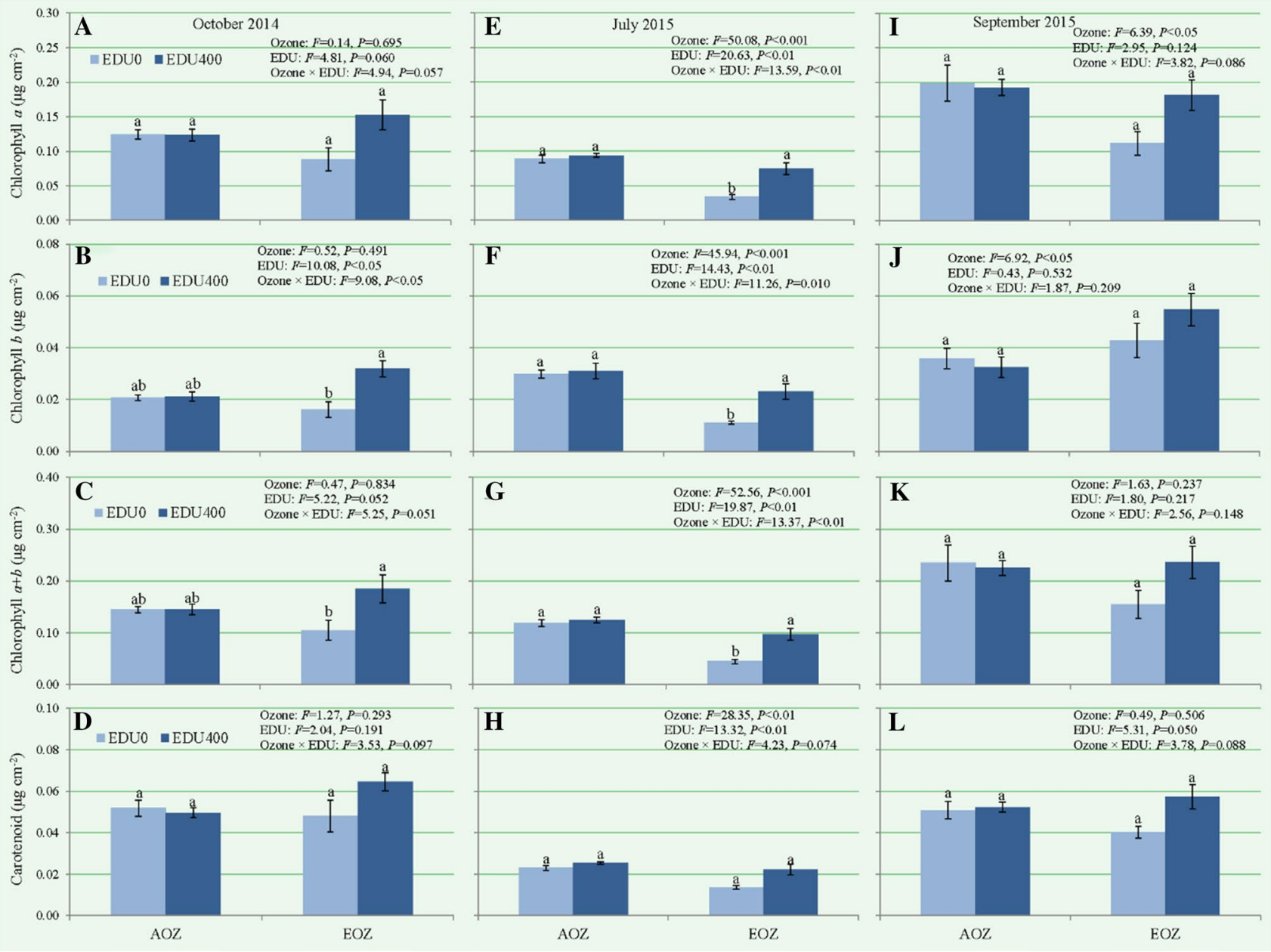

Fig. 2 Means $( \pm \mathrm{se})$ of photosynthetic pigments in hybrid larch plants grown in ambient ozone (AOZ) or elevated ozone (EOZ) and treated with $0 \mathrm{mg} \mathrm{L}^{-1}$ (EDU0) or $400 \mathrm{mg} \mathrm{L}^{-1}$ (EDU400) ethylenediurea (EDU) over three growing seasons. Photosynthetic pigments were evaluated in the first two growing seasons. The data were analyzed with a General Linear Model (GLM). Different letters above error bars indicate statistically significant differences according to Bonferroni posthoc test for significant interaction main effects. For nonsignificant interaction main effect, posthoc test was not performed, thus the means are marked with the same letters above error bars. The level of statistical significance was $\alpha=0.05$

$a$ (Fig. 2e), chlorophyll $b$ (Fig. 2f), and chlorophyll $a+b$ (Fig. 2g), EOZ-exposed plants treated with EDU400 had $120.8,108.3$, and $117.7 \%$ higher means, respectively, compared with EOZ-exposed plants treated with EDU0. The means of EOZ-exposed plants treated with EDU400 were not significantly different from the means of AOZ-exposed plants treated with either EDU0 or EDU400 for chlorophyll $a$ (Fig. 2e), chlorophyll $b$ (Fig. 2f), and chlorophyll $a+b$ (Fig. 2g).

In September, 2015, $\mathrm{O}_{3}$ had a significant main effect on all the pigment traits (Figs. 2i-j, 3e-f) except chlorophyll $a+b$ (Fig. 2k) and carotenoids (Fig. 2l). EOZ, relative to AOZ, decreased chlorophyll $a$ (Fig. 2i) by $33.5 \%$ and increased chlorophyll $b$ (Fig. 2 j) by $42.8 \%$ (Fig. 2c). Furthermore, plants had 2.3 and 1.4 times larger chlorophyll $a$ to $b$ (Fig. 3e) and chlorophyll to carotenoid (Fig. 3f) ratios in (Fig. 2h) and chlorophyll $a-b$ ratio (Fig. 3c). For chlorophyll 


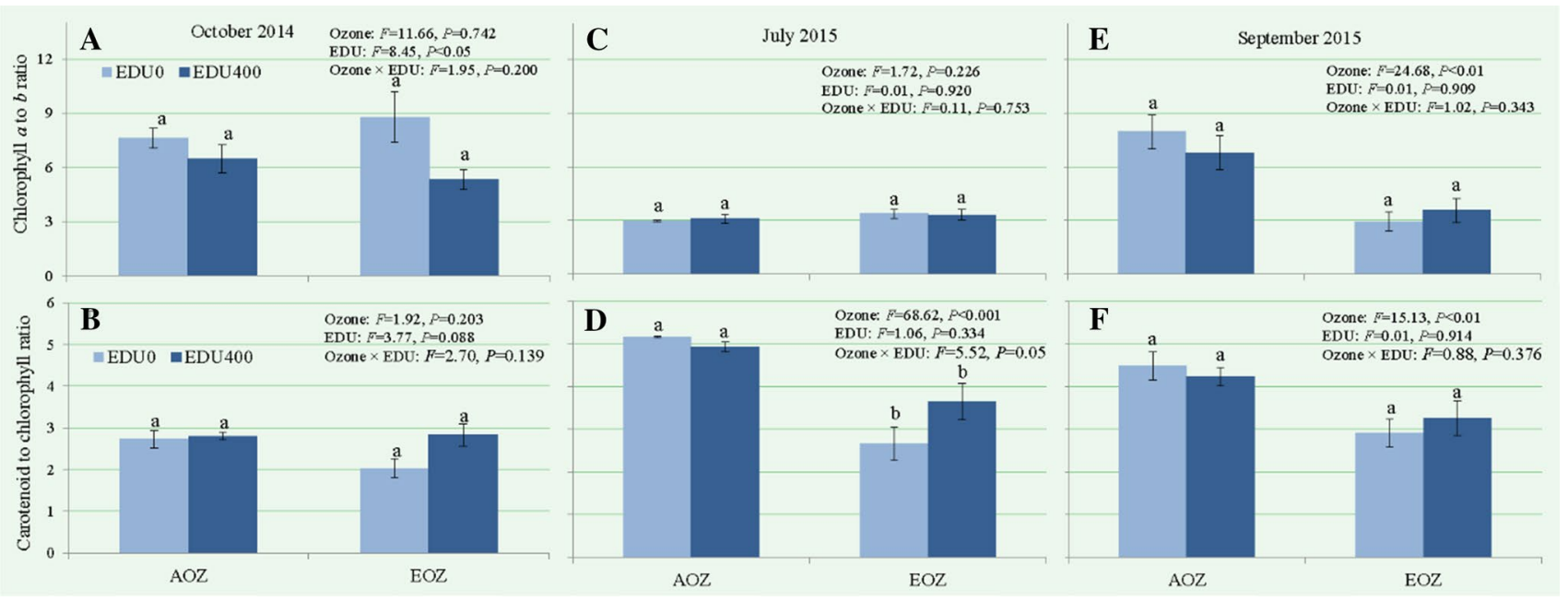

Fig. 3 Means $( \pm$ se) of chlorophylls ratio and carotenoid/chlorophyll ratio in hybrid larch plants grown in ambient ozone (AOZ) or elevated ozone (EOZ) and treated with $0 \mathrm{mg} \mathrm{L}^{-1}$ (EDU0) or $400 \mathrm{mg} \mathrm{L}^{-1}$ (EDU400) ethylenediurea (EDU) over three growing seasons. Photosynthetic pigments were evaluated in the first two growing seasons. The data were analyzed with a General Linear Model (GLM). Differ- ent letters above error bars indicate statistically significant differences according to Bonferroni posthoc test for significant interaction main effects. For non-significant interaction main effect, posthoc test was not performed, thus the means are marked with the same letters above error bars. The level of statistical significance was $\alpha=0.05$

marginally significant; however, there was no difference of biological relevance as to the treatments effect in the multiple comparisons (Fig. 5c). For the number of buds, all interactions were significant except $\mathrm{O}_{3} \times$ EDU (Fig. 5d). Regarding $\mathrm{O}_{3} \times$ Time interaction (significant at $P<0.05$ ), however, there was no relevant significant difference among means of $\mathrm{AOZ}$ and $\mathrm{EOZ}$ within each time point when tested with the "strict" Bonferroni test. Regarding EDU $\times$ Time interaction, there was no significant difference between EDU0 and EDU400 either before treatments (first growing season; time point 0 ) or in the spring of the second growing season (time point 1) (Fig. 5d). However, at the end of the third growing season (time point 2), plants treated with EDU400 had $16.6 \%$ more buds than plants treated with EDU0. Further examination of the $\mathrm{O}_{3} \times$ EDU $\times$ Time interaction revealed that this difference at the end of the third growing season appeared because EDU400 (average in $\mathrm{EOZ}=223.3$ buds) significantly protected $(+67.9 \%)$ buds of plants against EOZ, compared with EDU0 (average in $\mathrm{EOZ}=133.0$ buds). Moreover, EDU400 led to $31.4 \%$ more buds in plants exposed to EOZ compared to plants treated with EDU400 and exposed to AOZ. No significant difference was observed between AOZ-EDU0 and AOZ-EDU400 or between AOZ-EDU0 and EOZ-EDU400 treatments at the end of the third growing season (Fig. 5d). Neither was a significant difference observed among any treatments before the beginning of the treatments in the first growing season and one year later (spring of the second growing season). 


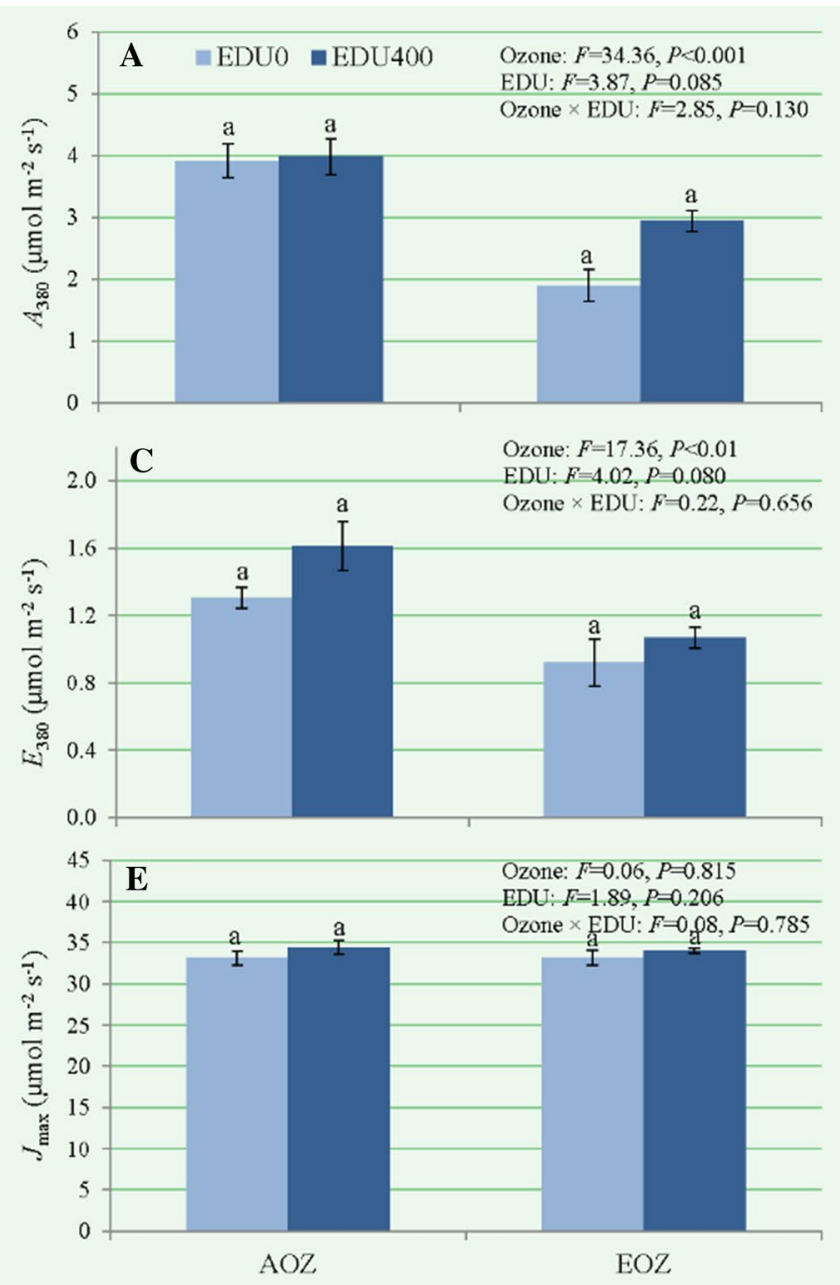

Fig. 4 Means $( \pm s e)$ of gas exchange traits of hybrid larch plants grown in ambient ozone (AOZ) or elevated ozone (EOZ) and treated with $0 \mathrm{mg} \mathrm{L}^{-1}$ (EDU0) or $400 \mathrm{mg} \mathrm{L}^{-1}$ (EDU400) ethylenediurea (EDU) over three growing seasons. Net photosynthetic rate $\left(A_{380}\right)$, stomatal conductance $\left(g_{380}\right)$, transpiration rate $\left(E_{380}\right)$, net photosynthetic rate at $1500 \mu \mathrm{mol} \mathrm{mol}^{-1}\left(A_{\max }\right)$ in the form of $\mathrm{CO}_{2}$, maximum rate of carboxylation $\left(V_{\mathrm{Cmax}}\right)$, and maximum rate of electron transport

In order to understand if the number of buds was due to smaller plants overall or because of fewer buds per unit biomass, the ratio of the total number of buds per plant at harvest to the dry mass of branches at harvest was analyzed. EDU was not a significant main factor, but $\mathrm{O}_{3}$ and $\mathrm{O}_{3} \times$ EDU interaction were significant main factors (Fig. 6). Conversely to the preceding analysis with the total number of buds per plants only, this further analysis per unit of branches biomass revealed that plants in AOZ (mean $=45.5 \pm 1.1$ buds, $n=6$ ) had $38.2 \%$ fewer buds per unit of branches biomass than plants in EOZ (mean $=62.7 \pm 5.1$ buds, $n=6$ ). The only significant differences among means were between EOZ-EDU0 vs. AOZEDU0 (-59.9\%) and AOZ-EDU400 (-55.0\%) (Fig. 6).
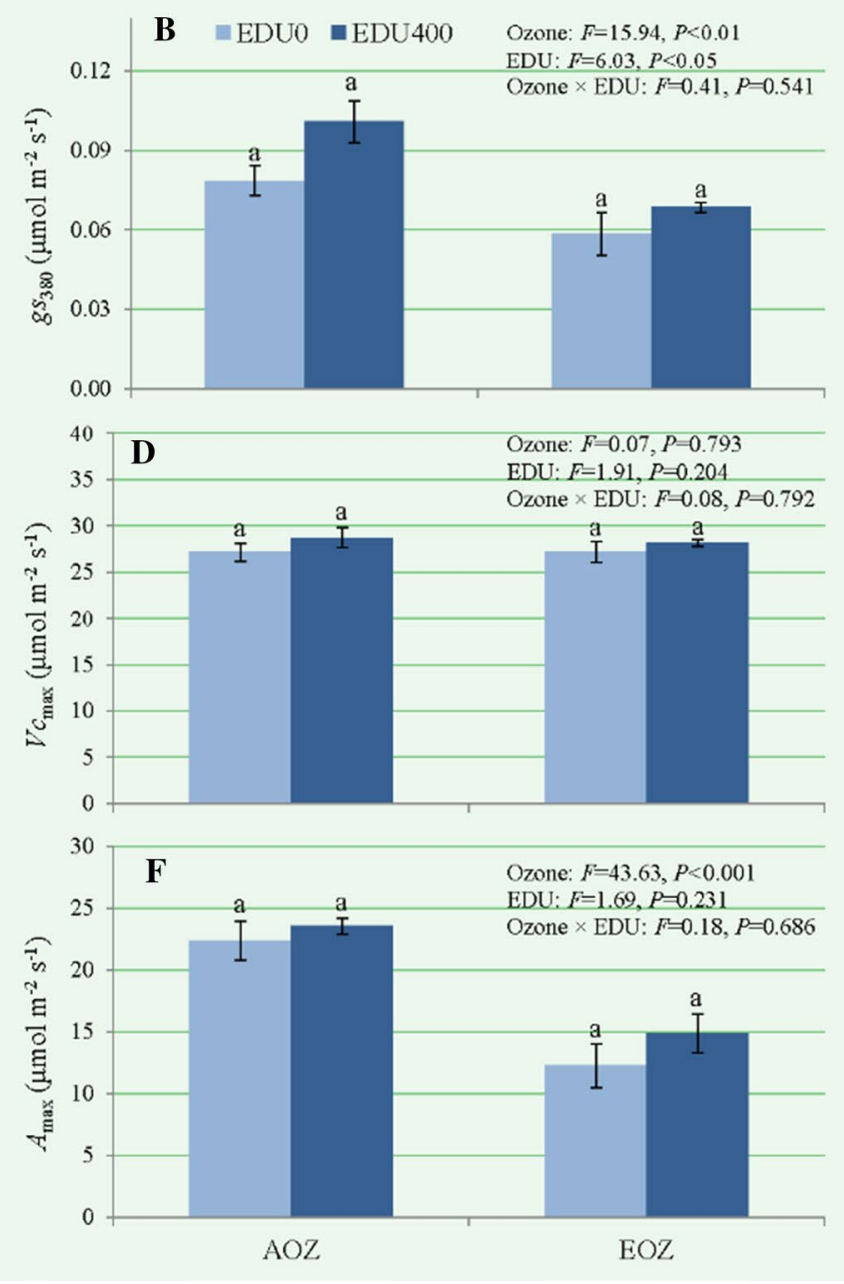

rate $\left(J_{\max }\right)$ were evaluated in late June, 2015 (second growing season). The data were analyzed with a General Linear Model (GLM). Different letters above error bars indicate statistically significant differences according to Bonferroni posthoc test for significant interaction main effects. For non-significant interaction main effect, posthoc test was not performed, thus the means are marked with the same letters above error bars. The level of statistical significance was $\alpha=0.05$

\section{Plant biomass}

Ozone main effect was not significant for stem + branches (Fig. 7a), needles (Fig. 7c), and shoot (Fig. 7d) biomass. However, EOZ significantly decreased root biomass by $52.1 \%$ (Fig. 7b), total plant biomass by $33.0 \%$ (Fig. 7e), and root/shoot ratio by $32.5 \%$ (Fig. 7f). EDU was a significant factor only for needles biomass (Fig. 7c) and shoot biomass (Fig. 7d), which were $54.9 \%$ and $31.9 \%$ higher in plants treated with EDU400 than in plants treated with EDU0. The $\mathrm{O}_{3} \times$ EDU interaction was significant for all the biomass traits (Fig. 7a-e) except root/shoot ratio (Fig. 7f). The same pattern was observed in the biomass traits with significant $\mathrm{O}_{3} \times$ EDU interaction: EDU400 protected plants against EOZ-induced inhibition. Specifically, EDU400 led 

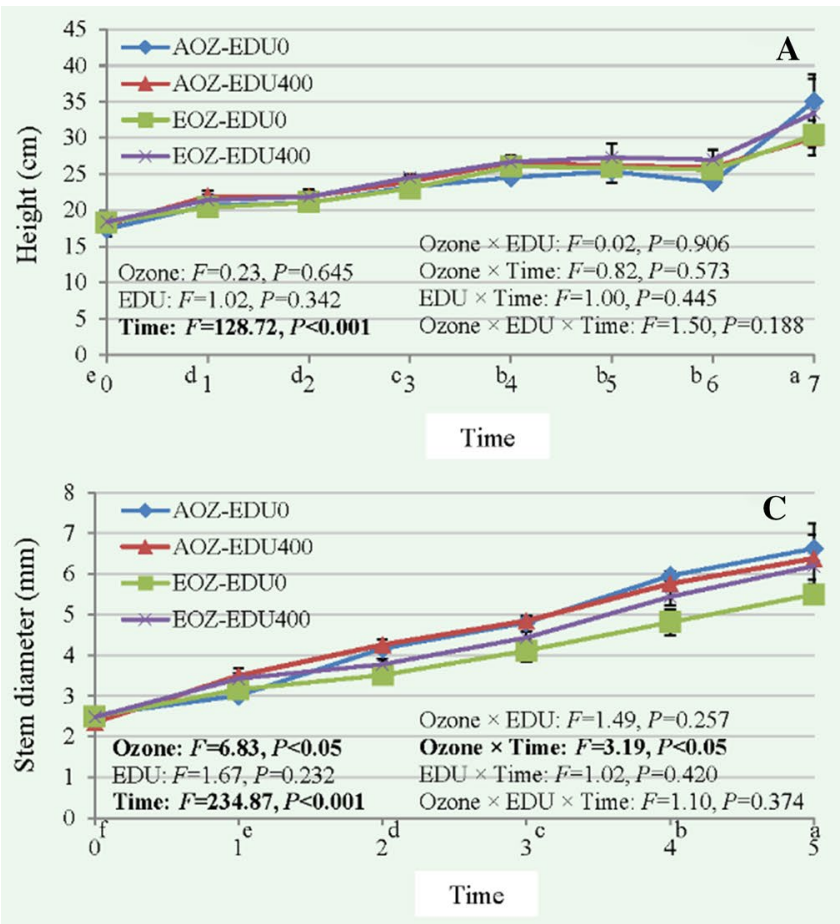

Fig. 5 Means $( \pm$ se) of growth and development traits of hybrid larch plants grown in ambient ozone (AOZ) or elevated ozone (EOZ) and treated with $0 \mathrm{mg} \mathrm{L}^{-1}$ (EDU0) or $400 \mathrm{mg} \mathrm{L}^{-1}$ (EDU400) ethylenediurea (EDU) over three growing seasons. The data were analyzed with a General Linear Model (GLM), followed by Bonferroni posthoc test for main effects with more than 2 levels. Different letters above time points indicate statistically significant differences for significant Time effect. Different letters above means indicate statistically significant differences for significant Ozone $\times$ EDU $\times$ Time interaction.

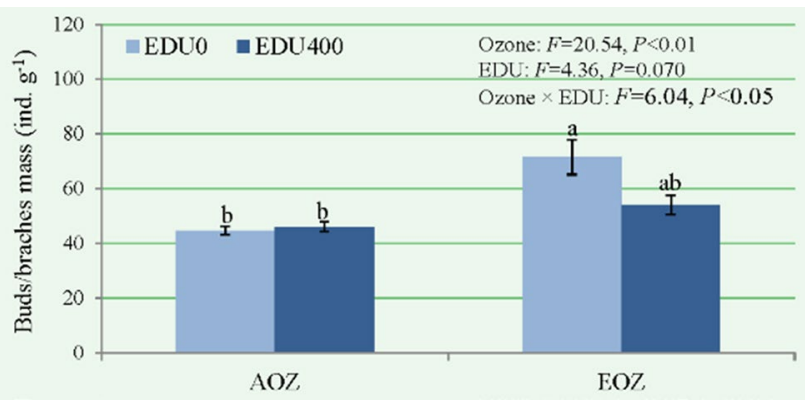

Fig. 6 Mean $( \pm$ se) of ratio of the total number of buds per plant at harvest to the dry mass of branches at harvest in hybrid larch plants grown in ambient ozone (AOZ) or elevated ozone (EOZ) and treated with $0 \mathrm{mg} \mathrm{L}^{-1}$ (EDU0) or $400 \mathrm{mg} \mathrm{L}^{-1}$ (EDU400) ethylenediurea (EDU) over three growing seasons. The data were analyzed with a General Linear Model (GLM). Different letters above bars indicate statistically significant differences according to Bonferroni posthoc test for significant interaction main effects. The level of statistical significance was $\alpha=0.05$
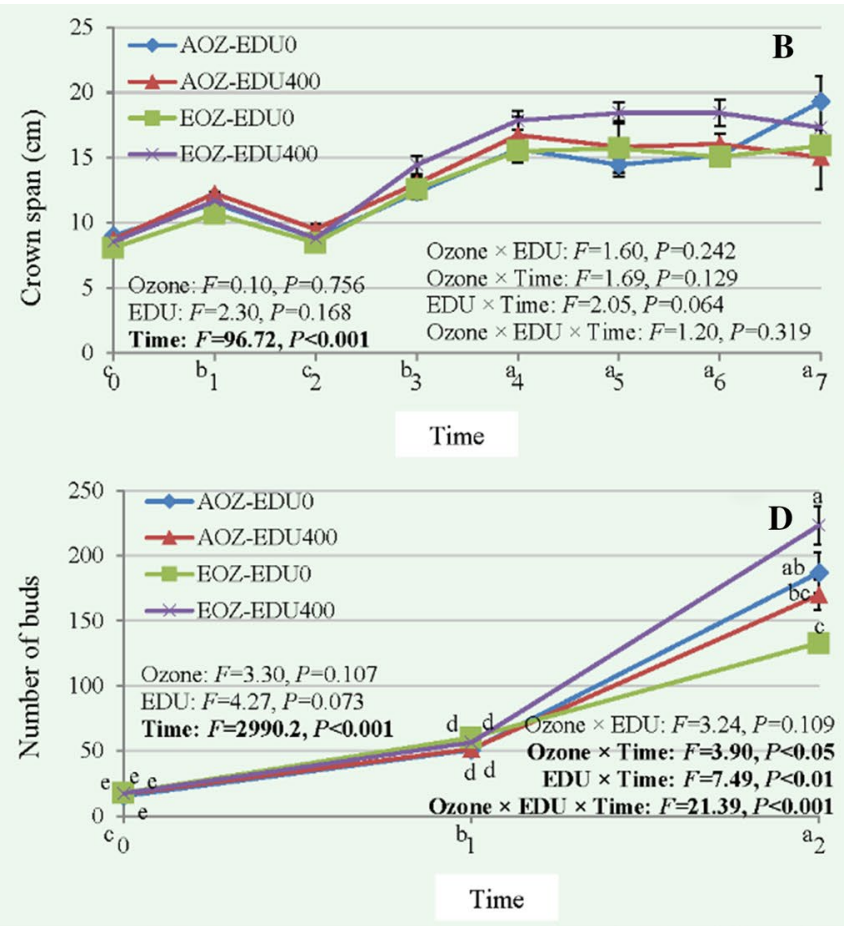

The level of statistical significance was $\alpha=0.05$. Note Following a pre-treatment measurement $(7 / 29 / 2014$; time point 0$)$, plant height (10/30/2014, 4/13/2015, 6/11/2015, 7/14/2015, 8/22/2015, 10/6/2015, $10 / 2 / 2016)$ and crown span $(10 / 30 / 2014,4 / 13 / 2015,6 / 11 / 2015$, $7 / 14 / 2015,8 / 22 / 2015,10 / 6 / 2015,10 / 2 / 2016)$ were measured 7 times post-treatment. Stem diameter was measured 5 times (10/30/2014, 4/13/2015, 7/14/2015, 10/6/2015, 10/2/2016) and number of buds was measured 2 times $(4 / 13 / 2015,10 / 2 / 2016)$ post-treatment

to $2.1,1.8,3.3,2.4$, and 2.2 times higher stem + branches (Fig. 7a), root (Fig. 7b), needles (Fig. 7c), shoot (Fig. 7d), and total plant (Fig. 7e) biomass, respectively, compared with EDU0, in EOZ. The mean of EOZ-EDU400 was not significantly different from the means of AOZ-EDU0 and AOZ-EDU400, except for needles biomass where the mean of EOZ-EDU400 was 1.6 times higher than the mean of AOZ-EDU400 (Fig. 7c).

\section{Leaf litter decay}

Ozone, EDU, and $\mathrm{O}_{3} \times$ EDU interaction were marginally significant for leaf litter decay (Fig. 8). Leaf litter from plants exposed to EOZ for two growing seasons had $35.5 \%$ less biomass than leaf litter from plants exposed to AOZ, following soil incubation for 74 days. Furthermore, leaf litter from plants treated with EDU400 in three growing seasons had $50.8 \%$ more biomass than leaf litter from plants treated with EDU0 (Fig. 8). The $\mathrm{O}_{3} \times$ EDU interaction had a pattern similar with that of most biomass traits, where EDU400 protected plants against EOZ impact. In particular, 


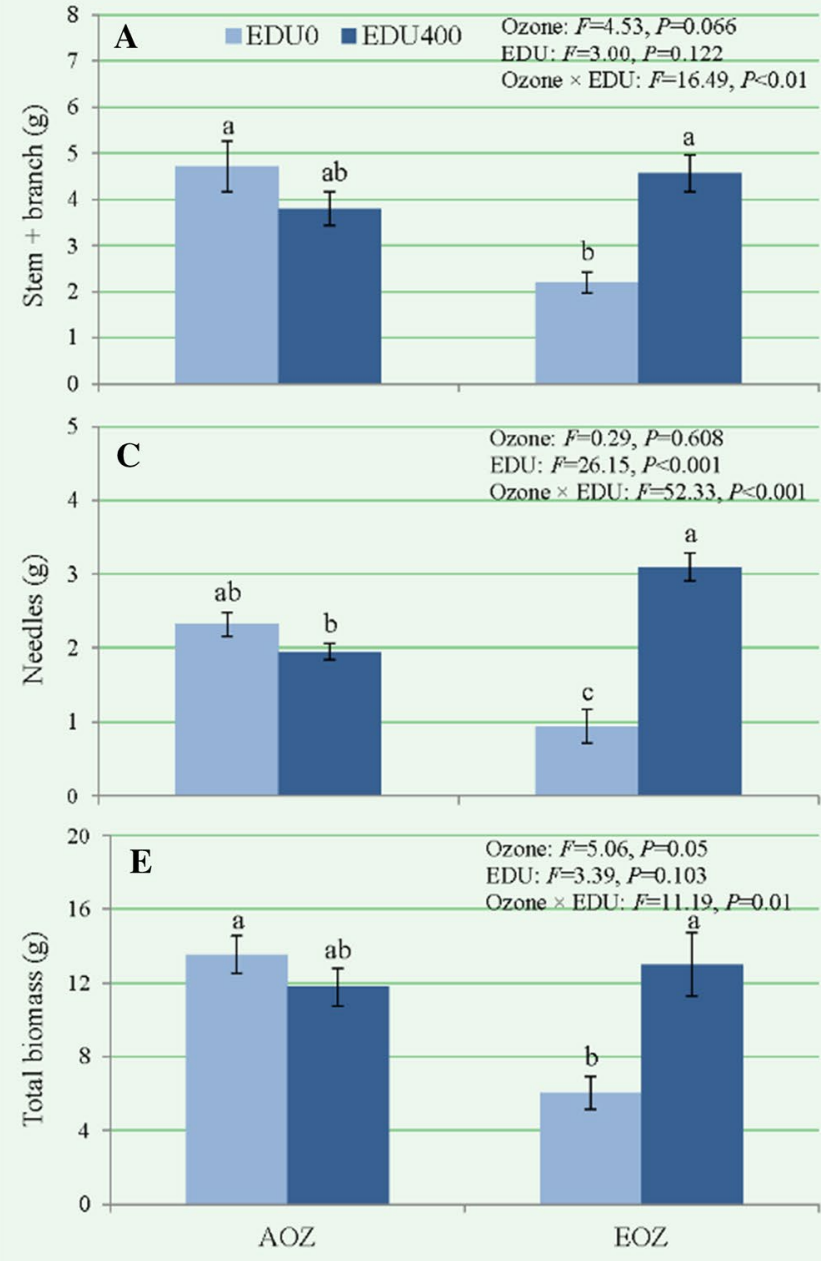

Fig. 7 Means $( \pm \mathrm{se})$ of biomass traits of hybrid larch plants grown in ambient ozone (AOZ) or elevated ozone (EOZ) and treated with $0 \mathrm{mg} \mathrm{L}^{-1}$ (EDU0) or $400 \mathrm{mg} \mathrm{L}^{-1}$ (EDU400) ethylenediurea (EDU) over three growing seasons. Biomass was evaluated at the end of the experiment. The data were analyzed with a General Linear Model (GLM). Different letters above bars indicate statistically significant differences according to Bonferroni posthoc test for significant interaction main effects. For non-significant interaction main effect,

the mean of EOZ-EDU0 was 2.2, 2.4, and 2.4 times smaller than the means of AOZ-EDU0, AOZ-EDU400, and EOZEDU400, respectively (Fig. 8). There was no significant difference among means of AOZ-EDU0, AOZ-EDU400, and EOZ-EDU400.

\section{Discussion}

\section{The overall picture of EDU protection against EOZ-induced phytotoxicity}

This research revealed significant negative effects of EOZ on hybrid larch plants, which appeared as extensive

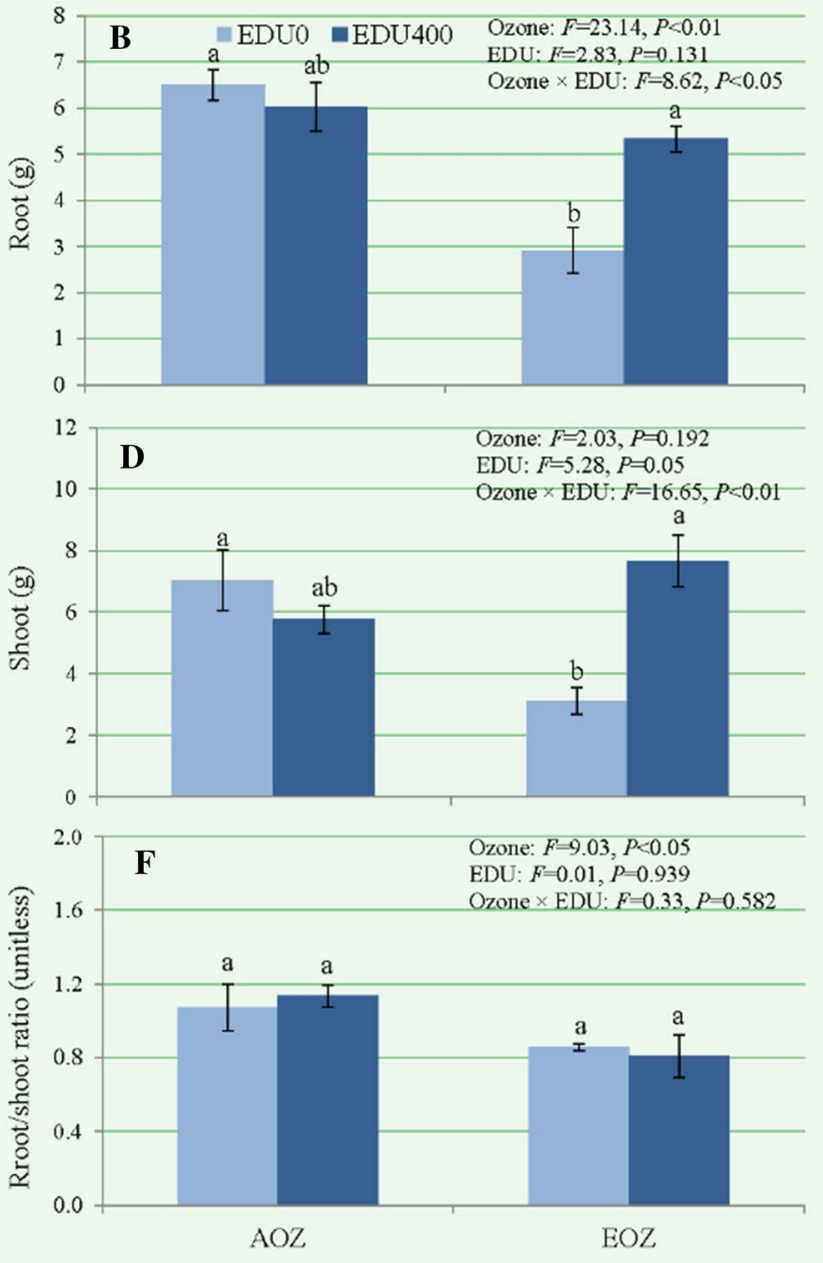

posthoc test was not performed, thus the means are marked with the same letters above error bars. The level of statistical significance was $\alpha=0.05$. Note: needles biomass $(C)$ does not include all the needles shed during the growing season, as severely-injured needles of EOZexposed plants were prematurely shed earlier than the normal senescence (and harvest), thus the impact of $\mathrm{O}_{3}$ on the needles biomass of EOZ-EDU0 plants is likely overestimated

visible foliar injury, premature senescence, suppressed gas exchange, inhibited stem diameter growth, suppressed biomass production, and impaired leaf litter decay. These findings suggest that hybrid larch is susceptible to elevated $\mathrm{O}_{3}$, in agreement with previous studies showing that hybrid and Japanese larches are susceptible to elevated $\mathrm{O}_{3}$ (Koike et al. 2012; Agathokleous et al. 2017, 2021). However, this research also revealed for the first time that EDU can protect against many of the negative effects of $\mathrm{O}_{3}$ on hybrid larch, with the potential to fully protect productivity and enhance the capacity for the next-year growth (based on number of buds). Positive effects of EDU on plants under $\mathrm{O}_{3}$ stress have been found in various trees and other types of perennial plants (Paoletti et al. 2009; Agathokleous 2017; Tiwari 


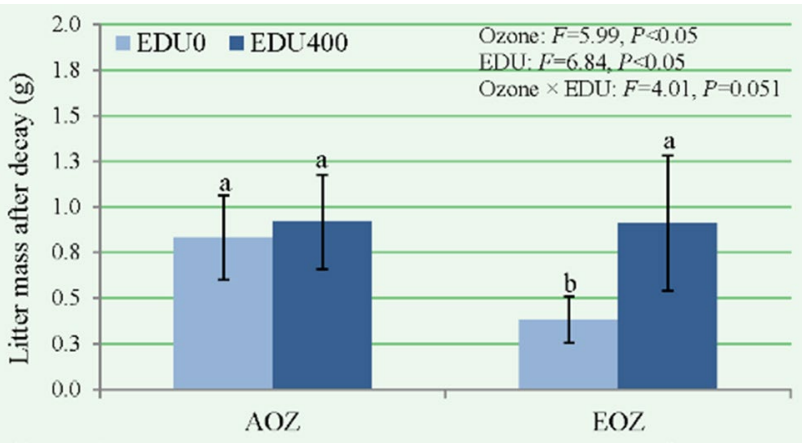

Fig. 8 Means $( \pm$ se) of leaf litter biomass after a 74-day decay in soil. Shed needles were obtained from hybrid larch plants grown in ambient ozone (AOZ) or elevated ozone (EOZ) and treated with $0 \mathrm{mg} \mathrm{L}^{-1}$ (EDU0) or $400 \mathrm{mg} \mathrm{L}^{-1}$ (EDU400) ethylenediurea (EDU) over three growing seasons. Shed needles were collected at the end of the second growing season (2015). The data were analyzed with a General Linear Model (GLM). Different letters above bars indicate statistically significant differences according to Bonferroni posthoc test for significant interaction main effects. The level of statistical significance was $\alpha=0.05$

2017; Salvatori et al. 2017; Rathore and Chaudhary 2019; Giovannelli et al. 2019; Xu et al. 2019; Agathokleous et al. 2021). However, among all the previous research programs with woody plants, only two studied the efficacy of EDU in protecting against $\mathrm{O}_{3}$ stress over multiple years, of which one including only ambient $\mathrm{O}_{3}$ with no $\mathrm{O}_{3}$ control (Giovannelli et al. 2019; Agathokleous et al. 2021). Therefore, this project is one of only two (Agathokleous et al. 2021) providing robust evidence that EDU can significantly protect woody species against elevated $\mathrm{O}_{3}$ (increased over current ambient) over multiple growing seasons.

\section{$\mathrm{O}_{3}$ and EDU effects on photosynthetic pigments}

Photosynthetic pigments are key response endpoints for assessing oxidative stress in plants (Agathokleous 2021), widely shown to be affected by $\mathrm{O}_{3}$ (Fiscus et al. 2005; Karnosky et al. 2007; Xin et al. 2016; Tiwari and Agrawal 2018; Feng et al. 2019b; Grulke and Heath 2020). For example, a meta-analysis of $\mathrm{O}_{3}$ effect on poplar revealed that elevated $\mathrm{O}_{3}\left(70-106 \mathrm{nmol} \mathrm{mol}^{-1}\right)$ and current ambient $\mathrm{O}_{3}\left(40-50 \mathrm{nmol} \mathrm{mol}^{-1}\right)$ decreased chlorophyll content by $34 \%$ and $13 \%$, compared with charcoal-filtered air (7-27 nmol mol ${ }^{-1}$ ) (Feng et al. 2019b). Another meta-analysis of $\mathrm{O}_{3}$ effects on woody plants also demonstrated that elevated $\mathrm{O}_{3}\left(88-98 \mathrm{nmol} \mathrm{mol}^{-1}\right)$ decreased chlorophyll $a$, chlorophyll $b$, chlorophyll $a+b$, and carotenoids by $17 \%$, $20 \%, 17 \%$, and $15 \%$, respectively; chlorophyll $a / b$ ratio was not significantly changed ( $\mathrm{Li}$ et al. 2017). A large suppression of photosynthetic pigment content and a small change in chlorophyll $a / b$ ratio were also found in Japanese and hybrid larch tall saplings grown in different soil types and exposed to ambient air or elevated $\mathrm{O}_{3}\left(\approx 66 \mathrm{nmol} \mathrm{mol}^{-1}\right)$ over two growing seasons (Agathokleous et al. 2017). Chlorophyll degradation follows palisade cells injury, resulting in more visible chlorotic flecks that are indicative of $\mathrm{O}_{3}$-stress symptomology in trees (Karnosky et al. 2007). Despite photosynthetic pigments exhibit a high temporal variability, it remains poorly understood how $\mathrm{O}_{3}$ affects photosynthetic pigments throughout time. The effect of EDU on woody plants grown under either ambient air or elevated $\mathrm{O}_{3}$ throughout time remains obscure.

The results of this study show that $\mathrm{O}_{3}$ and EDU effects on photosynthetic pigments varied with time. When measured in long-shoot needles in the fall of the first growing season, chlorophyll $b$ was more responsive to $\mathrm{O}_{3}$ and EDU than chlorophyll $a$. EDU400 increased chlorophyll $b$ content (50\%) and chlorophyll $a+b$ content (27\%), compared with EDU0, in EOZ. Moreover, EDU appeared to affect chlorophyll $b$ independently of $\mathrm{O}_{3}$, as EDU400 led to a lower chlorophyll $a$ to $b$ ratio (39\%, relative to EDU0), which indicates that it increased more chlorophyll $b$ content relative to chlorophyll $a$ content. Increased chlorophyll $b$ content (13\%, relative to EDU0) due to EDU (500 $\mathrm{mg} \mathrm{L}^{-1}$; applied once) was also found in Pinto bean plants (Phaseolus vulgaris $\mathrm{L}$.); $\mathrm{O}_{3}$ had no significant effect on chlorophyll $b$ content (Agathokleous et al. 2016b). These results together indicate that enhanced chlorophyll $b$, an accessory pigment occurring only in peripheral light-harvesting complexes and aiding in absorbing higher photons/blue light, may be an important mechanism of adaptive response by which EDU maximizes or optimizes light harvesting capacity and protect plants. By enhancing chlorophyll $b$, plants expand their light-harvesting antenna to attain a higher light-absorption efficiency per leaf unit, thus optimizing carbon balance and enhancing production capacity (Eggink et al. 2001) in Japanese larch seedlings treated with different light levels (Ji et al. 2015). That chlorophyll $b$ was sustained at relatively high levels under EOZ-induced stress when plants were treated with EDU400, allowing hybrid larch to better use light, suggests a consequently higher competitive capacity under light competition as found in Japanese larch grown with different light levels (Ji et al. 2015). Since several of these needles overwinter under snow to help plants regrow in the next growing season, this may be a mechanism to increase light absorption efficiency per leaf unit to aid plants increase their regrowth potential in the following spring. Physiologically, chlorophyll $b$ might be sustained at relatively high levels under EOZ-induced stress when plants were treated with EDU400 in the framework of an overcompensation response to protect chlorophyll $a$ and efficient energy transfer between chlorophyll $a$ molecules, control the antenna size, ensure the absorbance of high energy quantities, and/or dissipate excess energy (Sakuraba et al. 2010). 
Chlorophyll degradation occurs in the framework of autumn senescence in deciduous trees (Mattila et al. 2018). An increase in chlorophyll $a$ to $b$ ratio can also be an indicator of leaf senescence ( $\mathrm{Lu}$ et al. 2001). Ozone did not significantly affect (either alone or in interaction with EDU) chlorophyll $a$ to $b$ ratio in October, 2014, and July, 2015, and reduced chlorophyll $a$ to $b$ ratio in September, 2015. Considering also that most of the EOZ-damaged needles were already shed by the time the needles were sampled for pigment analyses, there is a possibility that younger needles of EOZ-exposed plants had enhanced stress-coping skills with decelerated senescence to protect plants. Furthermore, as EDU had a significant overall effect on chlorophyll $a$ to $b$ ratio $\left(\mathrm{O}_{3}\right.$ treatments pooled $)$ in October, 2014, EDU might have some effect on chlorophyll degradation. One speculation is that EDU might delay leaf senescence via a mode of action similar to $\mathrm{N}$ fertilizer (Van Heerwaarden et al. 2003; Fu et al. 2020). However, although EDU contains $\mathrm{N}$, abundant literature suggests that it does not act as a $\mathrm{N}$ fertilizer in plants (Agathokleous 2017), indicating a need for reconsideration of its basic mode of action in protecting plants against $\mathrm{O}_{3}$-induced toxicity. Here, a question is also raised whether $\mathrm{N}$ resorption in leaves of EOZ-exposed plants (Dong-Gyu et al. 2015) was protected by EDU, maybe due to keeping leaf longevity; however, $\mathrm{N}$ content in leaves and resorption was not evaluated in this research. As decomposition in chlorophyll-protein complexes has a relevant role in leaf $\mathrm{N}$ resorption, leaves of EOZ-exposed plants might also exhibit a delay in leaf $\mathrm{N}$ resorption. It may be postulated that not only early-shedding, but also a delay in the decomposition of chlorophyll-protein complexes might impair leaf $\mathrm{N}$ resorption under elevated $\mathrm{O}_{3}$, which should be further studied and confirmed experimentally.

In contrast to the long-shoot needles that showed relatively smaller effects of EOZ in the fall of the first growing season, short-shoot needles in mid. summer of the second growing season exhibited stronger effects of EOZ, as indicated by $70,78,71,36$, and $43 \%$ lower chlorophyll $a$, chlorophyll $b$, chlorophyll $a+b$, carotenoids, and chlorophyll to carotenoid ratio, respectively, in EOZ than in AOZ. However, chlorophyll $a$, chlorophyll $b$, and chlorophyll $a+b$ contents were fully protected by EDU400 against EOZ. These findings are similar with those in short-shoot needles in early fall of the second growing season, although EOZ had a relatively smaller effect than earlier in the summer, as indicated by 34 and $43 \%$ decreased chlorophyll $a$ and chlorophyll $b$ and a non-significantly affected chlorophyll $a+b$ content. The lower effect compared to summer might be also explained by the fact that the most $\mathrm{O}_{3}$-damaged needles had already been shed prematurely (see visible foliar injury in Fig. 1). Lower chlorophyll $a$ to $b$ and chlorophyll to carotenoid ratios due to EOZ suggest that EOZ affected plants by decreasing more chlorophyll $a$ than chlorophyll $b$ (EOZ tended to decrease chlorophyll $a$ but increase chlorophyll $b$ ) and more chlorophylls than carotenoids. While plants had 2.3 and 1.2 times lower chlorophyll $a$ to $b$ and chlorophyll to carotenoid ratios in EOZ than in AOZ, EDU did not protect against such changes. Such alterations in photosynthetic pigments ratios have been found in several studies with $\mathrm{O}_{3}$ and other abiotic stresses (Knudson et al. 1977; Saitanis et al. 2001; Sayyad-Amin et al. 2016). Besides, EDU had a significant effect (EDU400: $+20 \%$ relative to EDU0) on carotenoids only. Overall, across all time points, EOZ widely affected photosynthetic pigments and pigments ratios balance, commonly suppressing the light harvesting potential, and EDU400 alleviated many of the EOZ negative effects, but not all as its effect varied with trait and time point. A set of reasons may be involved in the variation in the effects from measurement time to measurement time, including (1) temporal variation of gas exchange physiology, (2) different age/type of leaf tissue analyzed, (3) time-dependent sensitivity of plants to $\mathrm{O}_{3}$ due to e.g. ontogenic stage and senescence processes, and (4) different $\mathrm{O}_{3}$ doses taken up by tissues at different time points, with the potential of accumulated oxidative stress over time.

\section{$\mathrm{O}_{3}$ and EDU effects on gas exchange}

In agreement with the EOZ effect on photosynthetic pigments in the summer of the second growing season, EOZ suppressed $A_{380}, g s_{380}, E_{380}$, and $A_{\max }$ by $63,41,47$, and $69 \%$, respectively, compared with $\mathrm{AOZ}$, but not $V c_{\max }$ and $J_{\max }$. However, EDU400 only increased (24\%) $g s_{380}$, compared with EDU0 $\left(\mathrm{O}_{3}\right.$ treatments pooled $)$, and had no significant effect on other gas exchange traits. These findings may indicate a conservative strategy of coordination between $V_{\mathrm{Cmax}}$ and $J_{\max }$ to counteract photoinhibition in the case of limiting carboxylation at the cost of maximizing photosynthesis at light-limiting conditions (Walker et al. 2014). These results also suggest that EDU mode of action against $\mathrm{O}_{3}$ damage was rather related to biochemical processes. However, it should be noted that the mode of action of EDU appears to be not only species-specific but also cultivar- or genotypespecific (Singh et al. 2015; Jiang et al. 2018; Feng et al. 2018; Pandey et al. 2019; Fatima et al. 2019).

\section{$\mathrm{O}_{3}$ and EDU effects on growth and productivity}

In this experiment, EOZ had only few effects on hybrid larch growth, which mainly appeared as inhibited stem diameter growth. Such limited effects of elevated $\mathrm{O}_{3}$ are in agreement with a recent study with Japanese larch saplings grown in the same soils and exposed to $\mathrm{O}_{3}$ in four growing seasons (Agathokleous et al. 2021). These findings highlight that experiments with woody plants grown in fertile/fertilized soils, i.e., the vast majority of studies in 
the literature of $\mathrm{O}_{3}$ effects on plants (see also Körner 1995, 2006), may overestimate effects of elevated $\mathrm{O}_{3}$, especially for larches that are naturally grown in nutrient-limited conditions (Schulze et al. 2019). However, EOZ significantly inhibited the total number of buds per plant in the third growing season (but not earlier), an effect that was minimized by EDU400. This novel finding that EOZ reduces the total number of buds in woody plants after multiple growing seasons, suggests that EOZ can adversely affect hybrid larch plant growth and competitive capacity in the next growing season. However, this effect could not be observed in the first growing season, suggesting that experiments lasting only one growing season may not be ideal to depict such effects. In support to this, other experiments with willow (Salix sachalinensis Fr. Schmidt) and Japanese larch exposed to $\mathrm{O}_{3}$ conditions similar with the ones in this study -but for only one growing season- did not find significantly changed number of buds due to $\mathrm{O}_{3}$ (Agathokleous et al. 2016a, 2021). To understand if the decreased number of plants was due to only smaller plants in EOZ (with no affected number of buds per unit of size), we standardized the total number of buds per plant (at harvest; the measurement conducted in the third growing season) according with the biomass of branches per plant (at harvest). Interestingly, this analysis revealed a significantly increased number of buds per unit of branches biomass due to EOZ, an effect that was mediated by EDU400. This response of EOZ-exposed plants treated with EDU0 may indicate an ecological strategy for investment to more buds per unit biomass to enhance the growth potential and competitive capacity in the next growing seasons. We did not find a paper reporting this kind of response to $\mathrm{O}_{3}$, regarding investment to buds, thus, this is the first study documenting this mechanism under $\mathrm{O}_{3}$ stress. Here, it should also be mentioned that the number of buds exhibited a larger effect $(\delta=10.11)$ relative to branches biomass $(\delta=2.82)$. This result cancels out the possibility that branches biomass exhibited a stronger effect of EOZ compared to the number of buds. In larch, the differentiation and development of buds as well as their responses to environmental changes have long been studied mainly for the artificial management of flowering promotion and the ecological managements under climate change (e.g., Heitmuller and Melchior 1960; Owens and Molder 1979, 2011; Sieber and Luscher 1995; Powell 1995; Ziauka and Kuusienë 2006; Owens 2008), suggesting that the plastic behavior of bud formation in response to environmental changes would be a unique characteristic of this larch. Our study further confirms this, using $\mathrm{O}_{3}$ as a different type of environmental stress (air pollutant), and provides a description of processing responses of individual leaves that may provide a perspective for further research to better understand the physiological mechanisms of such plastic responses of bud formation.

As a result of suppressed light-harvesting potential and photosynthetic capacity, EOZ inhibited root and total plant biomass, but not stem + branches, needles, and shoot biomass. These phenomena might be partly explained by the non-fertilized soil, simulating natural conditions, which led to limited effects of EOZ on plant aboveground growth. As a result, EOZ significantly decreased R/S ratio, which indicates that root was more affected than shoot in these non-fertilized soils, and such an effect may suggest negative effects for woody plant cultivation in the long term as a disproportional biomass of roots may not support well aboveground growth. The sensitivity of root biomass to elevated $\mathrm{O}_{3}$ has been shown by many studies ( $\mathrm{Li}$ et al. 2019; Pan et al. 2019, 2020; Mrak et al. 2019, 2020; Tisdale et al. 2021), commonly with fertile soils, with a reduced allocation to the roots (compared to the shoots) occurring in many cases (Grantz et al. 2006). EDU400 did not mediate the EOZinduced effect on the $\mathrm{R} / \mathrm{S}$ ratio; however, it minimized $\mathrm{EOZ}$ effect on stem + branches, root, needles, shoot, and total plant biomass. These results suggest that EDU400 could minimize EOZ-induced biomass losses, but it offered a higher degree of protection to shoot (compared to root), even if it was applied to plant root (soil drench). Furthermore, biomass allocation responded to EOZ even under EDU400, but EOZ-induced accelerated leaf senescence was effectively circumvented by EDU400. The preferable biomass allocation into shoot under $\mathrm{O}_{3}$ stress, irrespective of EDU, may suggest that plants perceived $\mathrm{O}_{3}$ as a signal of preferential accumulation to shoot, even in the presence of EDU400. Enhancement of shoot growth by $\mathrm{O}_{3}$ was also found in studies with different tree species (Kitao et al. 2015). Based on the results, EDU might have not prevented $\mathrm{O}_{3}$ uptake in the plant tissue interior, but might have enhanced the stability of some function regarding leaf senescence. EDU might contribute to maintaining membrane integrity, which increases tolerance to $\mathrm{O}_{3}$ (i.e., preventing leaf senescence), as it has been reported for volatile organic compounds function or drought-enhanced tolerance to heat (Zhang et al. 2019). However, further studies are needed to test these hypotheses.

\section{$\mathrm{O}_{3}$ and EDU effects on leaf litter decay}

Making a further step, this research evaluated for the first time the potential effect of EDU on the decay of leaf litter of EOZ-exposed plants. Although the incubation of litter bags was relatively short, the results showed a significantly lower mass of leaf litter following a 74-day decay when litter was exposed to EOZ (compared to AOZ), suggesting that leaf litter from EOZ-exposed plants exhibited a higher/faster decay than leaf litter from AOZ-exposed plants. This study did not aim to investigate the underpinning mechanisms of 
the difference in decay but used the amount of decayed biomass as an index of health that may translate to effects on the community and ecosystem. Therefore, the reason(s) for the higher decay of leaf litter from EOZ compared to leaf litter from $\mathrm{AOZ}$ remain(s) unknown. For example, it might be even due to difference in the type of leaf litter as EOZexposed plants (in particular those of EDU0 group) lost most of the severely $\mathrm{O}_{3}$-injured needles before litter collection. Another explanation is that EOZ-EDU0 leaves of hybrid larch might have higher litter N (Dong-Gyu et al. 2015), although not analyzed in this study. A few studies showed before that $\mathrm{O}_{3}$ can alter the decomposition process using various plant species (Boerner and Rebbeck 1995; Baldantoni et al. 2013), albeit there is a discrepancy in the findings (Parsons et al. 2004, 2008; Lindroth 2010; Vitale et al. 2019). Ozone slowed down (Parsons et al. 2008; Baldantoni et al. 2013; Fu et al. 2018), enhanced (Fenn and Dunn 1989; Boerner and Rebbeck 1995; Parsons et al. 2008; Fu et al. 2018), or did not significantly affect (Boerner and Rebbeck 1995; Fu et al. 2018) biomass loss of leaf litter. These differences can be attributed to various factors such as species, incubation duration, and $\mathrm{O}_{3}$ exposure characteristics. Similar to our findings, more mass remained in leaf litter of yellow poplar (Liriodendron tulipifera L.) exposed to ambient or elevated $\mathrm{O}_{3}$ (relative to charcoal-filtered air) in the first 10 months of incubation, but these differences no longer existed by the end of the year (Boerner and Rebbeck 1995). Likewise, elevated $\mathrm{O}_{3}$ decelerated the leaf litter (Ginkgo biloba L.) decomposition early in the incubation period and slightly accelerated it in later stages of the incubation (Fu et al. 2018). While the difference in decay rate may be temporal, it may have implications to various ecological processes, including nutrient cycling processes. That EDU400 fully protected from the EOZ-induced alteration of leaf litter decay suggests for the first time that positive effects of EDU on plants may have further protection of soil community/ ecosystem.

\section{Conclusion}

To conclude, EOZ led to various adverse effects on the hybrid larch plants, spanning from the leaf level (pigments, gas exchange) to the level of individual (biomass, number of buds) as well as leaf litter decay, and EDU400 minimized most of the EOZ-induced effects. A novel ecological strategy of plants under $\mathrm{O}_{3}$ stress was also revealed, in the framework of which hybrid larch saplings increased the investment toward enhanced development of buds per unit of branches biomass in EOZ, an effect that was mediated by EDU400. This strategy may be attributed to an effort of plants to increase their growth potential and competitiveness in the next growing season. The protection of plants by
EDU400 was mainly due to a biochemical mode of action. All in all, EDU400 can be considered as a tool to improve this heterosis-displaying hybrid larch with superior characteristics under elevated $\mathrm{O}_{3}$ conditions in the future.

Acknowledgements The authors are grateful to Mr. Tatsushiro Ueda (engineer; Dalton Co., Hokkaido Branch, Japan) for assistance in regulating the $\mathrm{O}_{3}$-exposure system during the experiment. They are also thankful to Dr. William J. Manning, Emer. Prof. at the University of Massachusetts, Amherst, USA, for kindly providing ethylenediurea. E.A. acknowledges multi-year support from The Startup Foundation for Introducing Talent of Nanjing University of Information Science \& Technology (NUIST), Nanjing, China (Grant No. 003080).

Open Access This article is licensed under a Creative Commons Attribution 4.0 International License, which permits use, sharing, adaptation, distribution and reproduction in any medium or format, as long as you give appropriate credit to the original author(s) and the source, provide a link to the Creative Commons licence, and indicate if changes were made. The images or other third party material in this article are included in the article's Creative Commons licence, unless indicated otherwise in a credit line to the material. If material is not included in the article's Creative Commons licence and your intended use is not permitted by statutory regulation or exceeds the permitted use, you will need to obtain permission directly from the copyright holder. To view a copy of this licence, visit http://creativecommons.org/licenses/by/4.0/.

\section{References}

Agathokleous E (2017) Perspectives for elucidating the ethylenediurea (EDU) mode of action for protection against $\mathrm{O}_{3}$ phytotoxicity. Ecotoxicol Environ Safe 142:530-537. https://doi.org/10.1016/j. ecoenv.2017.04.057

Agathokleous E (2021) The rise and fall of photosynthesis: hormetic dose response in plants. J For Res 32:789-803. https://doi.org/ 10.1007/s11676-020-01252-1

Agathokleous E, Paoletti E, Saitanis CJ, Manning WJ, Sugai T, Koike $\mathrm{T}$ (2016a) Impacts of ethylenediurea (EDU) soil drench and foliar spray in Salix sachalinensis protection against $\mathrm{O}_{3}$-induced injury. Sci Total Environ 573:1053-1062. https://doi.org/10.1016/j.scito tenv.2016.08.183

Agathokleous E, Saitanis CJ, Stamatelopoulos D, Mouzaki-Paxinou A-C, Paoletti E, Manning WJ (2016b) Olive oil for dressing plant leaves so as to avoid $\mathrm{O}_{3}$ injury. Water Air Soil Pollut 227:282. https://doi.org/10.1007/s11270-016-2986-9

Agathokleous E, Vanderstock A, Kita K, Koike T (2017) Stem and crown growth of Japanese larch and its hybrid $\mathrm{F}_{1}$ grown in two soils and exposed to two free-air $\mathrm{O}_{3}$ regimes. Environ Sci Pollut Res 24:6634-6647. https://doi.org/10.1007/s11356-017-8401-2

Agathokleous E, Kitao M, Wang X, Mao Q, Harayama H, Manning WJ, Koike T (2021) Ethylenediurea (EDU) effects on Japanese larch: an one growing season experiment with simulated regenerating communities and a four growing season application to individual saplings. J For Res 31:2295-2311. https://doi.org/10. 1007/s11676-020-01223-6

Ashrafuzzaman M, Haque Z, Ali B, Mathew B, Yu P, Hochholdinger F, de Abreu Net JB, McGillen MR, Ensikat H-J, Manning WJ, Frei M (2018) Ethylenediurea (EDU) mitigates the negative effects of ozone in rice: insights into its mode of action. Plant Cell Environ 41:2882-2898. https://doi.org/10.1111/pce.13423 
Baldantoni D, Bellino A, Manes F, Alfani A (2013) Ozone fumigation of Quercus ilex L. slows down leaf litter decomposition with no detectable change in leaf composition. Ann for Sci 70:571-578. https://doi.org/10.1007/s13595-013-0297-5

Barnes JD, Balaguer L, Manrique E, Elvira S, Davison AW (1992) A reappraisal of the use of DMSO for the extraction and determination of chlorophylls $a$ and $b$ in lichens and higher plants. Environ Exp Bot 32:85-100. https://doi.org/10.1016/0098-8472(92) 90034-y

Bellini E, De Tullio MC (2019) Ascorbic acid and ozone: novel perspectives to explain an elusive relationship. Plants 8:122. https:// doi.org/10.3390/plants8050122

Berg EE, Chapin FS III (1994) Needle loss as a mechanism of winter drought avoidance in boreal conifers. Can J for Res 24:11441148. https://doi.org/10.1139/x94-151

Blande JD (2021) Effects of air pollution on plant-insect interactions mediated by olfactory and visual cues. Curr Opin Environ Sci Heal 19:100228. https://doi.org/10.1016/j.coesh.2020.100228

Boerner REJ, Rebbeck J (1995) Decomposition and nitrogen release from leaves of three hardwood species grown under elevated $\mathrm{O}_{3}$ and/or $\mathrm{CO}_{2}$. Plant Soil 170:149-157. https://doi.org/10. 1007/bf02183063

Cieslik S, Omasa K, Paoletti E (2009) Why and how terrestrial plants exchange gases with air. Plant Biol 11:24-34. https://doi.org/ 10.1111/j.1438-8677.2009.00262.x

Diaz FMR, Khan MAH, Shallcross BMA, Shallcross EDG, Vogt U, Shallcross DE (2020) Ozone trends in the United Kingdom over the last 30 years. Atmosphere 11:534. https://doi.org/10. 3390/atmos11050534

Dong-Gyu K, Shi C, Watanabe M, Kita K, Satoh F, Koike T (2015) Growth of Japanese and hybrid larch seedlings grown under free-air $\mathrm{O}_{3}$ fumigation-an initial assessment of the effects of adequate and excessive nitrogen. J Agr Meteorol 71:239-244. https://doi.org/10.2480/agrmet.d-14-00029

Eggink LL, Park H, Hoober JK (2001) The role of chlorophyll $b$ in photosynthesis: hypothesis. BMC Plant Biol 1:2. https://doi. org/10.1186/1471-2229-1-2

Farquhar GD, von Caemmerer S, Berry JA (1980) A biochemical model of photosynthetic $\mathrm{CO}_{2}$ assimilation in leaves of $\mathrm{C}_{3}$ species. Planta 149:78-90. https://doi.org/10.1007/BF00386231

Fatima A, Singh AA, Mukherjee A, Dolker T, Agrawal M, Agrawal SB (2019) Assessment of ozone sensitivity in three wheat cultivars using ethylenediurea. Plants 8:80. https://doi.org/10. 3390/plants 8040080

Feng Z, Wang S, Szantoi Z, Chen S, Wang X (2010) Protection of plants from ambient ozone by applications of ethylenediurea (EDU): a meta-analytic review. Environ Pollut 158:3236-3242. https://doi.org/10.1016/j.envpol.2010.07.009

Feng Z, Jiang L, Calatayud V, Dai L, Paoletti E (2018) Intraspecific variation in sensitivity of winter wheat (Triticum aestivum L.) to ambient ozone in northern China as assessed by ethylenediurea (EDU). Environ Sci Pollut Res 25:29208-29218. https:// doi.org/10.1007/s11356-018-2782-8

Feng Z, Kobayashi K, Li P, Xu Y, Tang H, Guo A, Paoletti E, Calatayud V (2019a) Impacts of current ozone pollution on wheat yield in China as estimated with observed ozone, meteorology and day of flowering. Atmos Environ 217:116945. https://doi. org/10.1016/j.atmosenv.2019.116945

Feng Z, Shang B, Gao F, Calatayud V (2019b) Current ambient and elevated ozone effects on poplar: a global meta-analysis and response relationships. Sci Total Environ 654:832-840. https:// doi.org/10.1016/j.scitotenv.2018.11.179

Feng Z, Hu T, Tai APK, Calatayud V (2020) Yield and economic losses in maize caused by ambient ozone in the North China Plain (2014-2017). Sci Total Environ 722:137958. https://doi. org/10.1016/j.scitotenv.2020.137958
Fenn ME, Dunn PH (1989) Litter decomposition across an air-pollution gradient in the San Bernardino mountains. Soil Sci Soc Am J 53:1560-1567. https://doi.org/10.2136/sssaj1989.03615 $995005300050044 x$

Fiscus EL, Booker FL, Burkey KO (2005) Crop responses to ozone: uptake, modes of action, carbon assimilation and partitioning. Plant Cell Environ 28:997-1011. https://doi.org/10.1111/j. 1365-3040.2005.01349.x

Fu W, He X, Xu S, Chen W, Li Y, Li B, Su L, Ping Q (2018) Changes in nutrients and decay rate of Ginkgo biloba leaf litter exposed to elevated $\mathrm{O}_{3}$ concentration in urban area. PeerJ 6:e4453. https://doi.org/10.7717/peerj.4453

Fu W, Wang Y, Ye Y, Zhen S, Zhou B, Wang Y, Hu Y, Zhao Y, Huang Y (2020) Grain yields and nitrogen use efficiencies in different types of stay-green maize in response to nitrogen fertilizer. Plants 9:474. https://doi.org/10.3390/plants9040474

Fuhrer J, Val Martin M, Mills G, Heald CL, Harmens H, Hayes F, Sharps K, Bender J, Ashmore MR (2016) Current and future ozone risks to global terrestrial biodiversity and ecosystem processes. Ecol Evol 6:8785-8799. https://doi.org/10.1002/ece3. 2568

Gao M, Gao J, Zhu B, Kumar R, Lu X, Song S, Zhang Y, Jia B, Wang P, Beig G, Hu J, Ying Q, Zhang H, Sherman P, McElroy MB (2020) Ozone pollution over China and India: seasonality and sources. Atmos Chem Phys 20:4399-4414. https://doi.org/10. 5194/acp-20-4399-2020

Giovannelli A, Traversi ML, Anichini M, Hoshika Y, Fares S, Paoletti E (2019) Effect of long-term vs. short-term ambient ozone exposure on radial stem growth, sap flux and xylem morphology of O3-sensitive poplar trees. Forests 10:396. https://doi.org/10. 3390/f10050396

Givnish TJ (2002) Adaptive significance of evergreen vs. deciduous leaves: solving the triple paradox. Silva Fenn 36:703-743. https://doi.org/10.14214/sf.535

Gower ST, Richards JH (1990) Larches: deciduous conifers in an evergreen world. Bioscience 40:818-826. https://doi.org/10.2307/ 1311484

Grantz DA, Gunn S, Vu H-B (2006) $\mathrm{O}_{3}$ impacts on plant development: a meta-analysis of root/shoot allocation and growth. Plant Cell Environ 29:1193-1209. https://doi.org/10.1111/j.1365-3040. 2006.01521.x

Grulke NE, Heath RL (2020) Ozone effects on plants in natural ecosystems. Plant Biol 22:12-37. https://doi.org/10.1111/plb.12971

Heitmüller HH, Melchior GH (1960) Über die Blühfördernde Wirkung des Wurzelschnitts, des Zweigkrümmens und der Strangulation an Japanis-cher Lärche (Larix leptolepis (Sieb \& Zucc) Gord). Silvae Genet 9:65-72

Howell DC, Mcconaughy SH (1982) Nonorthogonal analysis of variance: putting the question before the answer. Educ Psychol Meas 42:9-24. https://doi.org/10.1177/0013164482421002

Hu T, Liu S, Xu Y, Feng Z, Calatayud V (2020) Assessment of $\mathrm{O}_{3}$-induced yield and economic losses for wheat in the North China Plain from 2014 to 2017. China Environ Pollut 258:113828. https://doi.org/10.1016/j.envpol.2019.113828

Izuta T (2017) Air pollution impacts on plants in East Asia. Springer, Tokyo

Ji DH, Mao QZ, Watanabe Y, Kitao M, Kitaoka S (2015) Effect of nitrogen loading on the growth and photosynthetic responses of Japanese larch seedlings grown under different light regimes. J Agr Met 71:232-238. https://doi.org/10.2480/agrmet. D-14-00027

Jiang L, Feng Z, Dai L, Shang B, Paoletti E (2018) Large variability in ambient ozone sensitivity across 19 ethylenediurea-treated Chinese cultivars of soybean is driven by total ascorbate. J Environ Sci 64:10-22. https://doi.org/10.1016/j.jes.2017.07.002 
Käffer MI, Domingos M, Lieske I, Vargas VMF (2019) Predicting ozone levels from climatic parameters and leaf traits of Bel-W3 tobacco variety. Environ Pollut 248:471-477. https://doi.org/10. 1016/j.envpol.2019.01.130

Karnosky DF, Skelly JM, Percy KE, Chappelka AH (2007) Perspectives regarding 50 years of research on effects of tropospheric ozone air pollution on US forests. Environ Pollut 147:489-506. https://doi.org/10.1016/j.envpol.2006.08.043

Kinose Y, Fukamachi Y, Watanabe M, Izuta T (2020) Ozone-induced change in the relationship between stomatal conductance and net photosynthetic rate is a factor determining cumulative stomatal ozone uptake by Fagus crenata seedlings. Trees - Struct Funct 34:445-454. https://doi.org/10.1007/s00468-019-01927-1

Kitao M, Komatsu M, Yazaki K, Kitaoka S, Tobita H (2015) Growth overcompensation against $\mathrm{O}_{3}$ exposure in two Japanese oak species, Quercus mongolica var. crispula and Quercus serrata, grown under elevated $\mathrm{CO}_{2}$. Environ Pollut 206:133-141. https://doi.org/10.1016/j.envpol.2015.06.034

Kitaoka S, Laiye Q, Watanabe Y, Watanabe M, Watanabe T, Koike T (2020) Heterophyllous shoots of japanese larch trees: the seasonal and yearly variation in $\mathrm{CO}_{2}$ assimilation capacity of the canopy top with changing environment. Plants 9:1278. https:// doi.org/10.3390/plants9101278

Knudson LLL, Tibbitts TWW, Edwards GEE (1977) Measurement of ozone injury by determination of leaf chlorophyll concentration. Plant Physiol 60:606-608. https://doi.org/10.1104/pp. 60.4.606

Koike T, Mao Q, Inada N, Kawaguchi K, Hoshika Y, Kita K, Watanabe M (2012) Growth and photosynthetic responses of cuttings of a hybrid larch (Larix gmelinii var. japonica $\times$ L. kaempferi) to elevated ozone and/or carbon dioxide. Asian J Atmos Environ 6:104-110. https://doi.org/10.5572/ajae.2012.6.2.104

Koike T, Watanabe M, Hoshika Y, Kitao M, Matsumura H, Funada R, Izuta T (2013) Effects of ozone on forest ecosystems in East and Southeast Asia. Elsevier Develop Environ Sci 13:371-390. https://doi.org/10.1016/b978-0-08-098349-3.00017-7

Körner C (1995) Towards a better experimental basis for upscaling plant responses to elevated $\mathrm{CO}_{2}$ and climate warming. Plant, Cell Environ 18:1101-1110. https://doi.org/10.1111/j.1365-3040. 1995.tb00622.x

Körner C (2006) Plant $\mathrm{CO}_{2}$ responses: an issue of definition, time and resource supply. New Phytol 172:393-411. https://doi.org/10. 1111/j.1469-8137.2006.01886.x

Kurahashi A (1988) Improvement of larches by species Hybridization. Bull Tokyo Univ Forests 79:1-94 (in Japanese with English summary)

Kurinobu S (2015) Forest tree breeding for Japanese larch. Eurasian J For Res 8-2:127-134

Li P, Feng Z, Catalayud V, Yuan X, Xu Y, Paoletti E (2017) A metaanalysis on growth, physiological, and biochemical responses of woody species to ground-level ozone highlights the role of plant functional types. Plant Cell Environ 40:2369-2380. https://doi. org/10.1111/pce.13043

Li P, Zhou H, Xu Y, Shang B, Feng Z (2019) The effects of elevated ozone on the accumulation and allocation of poplar biomass correlate strongly to water and nitrogen availability. Sci Total Environ 665:929-936. https://doi.org/10.1016/j.scitotenv.2019.02.182

Lichtenthaler HK (1987) Chlorophylls and carotenoids pigments of photosynthetic biomembranes. Methods Enzymol 148:350-382. https://doi.org/10.1016/0076-6879(87)48036-1

Lindroth RL (2010) Impacts of elevated atmospheric $\mathrm{CO}_{2}$ and $\mathrm{O}_{3}$ on forests: phytochemistry, trophic interactions, and ecosystem dynamics. J Chem Ecol 36:2-21. https://doi.org/10.1007/ s10886-009-9731-4

Long SP, Bernacchi CJ (2003) Gas exchange measurements, what can they tell us about the underlying limitations to photosynthesis?
Procedures and sources of error. J Exp Bot 54:2393-2401. https://doi.org/10.1093/jxb/erg262

Lu C, Lu Q, Zhang J, Kuang T (2001) Characterization of photosynthetic pigment composition, photosystem II photochemistry and thermal energy dissipation during leaf senescence of wheat plants grown in the field. J Exp Bot 52:1805-1810. https://doi. org/10.1093/jexbot/52.362.1805

Manning W, Paoletti E, Sandermann H, Ernst D (2011) Ethylenediurea (EDU): a research tool for assessment and verification of the effects of ground level ozone on plants under natural conditions. Environ Pollut 159:3283-3293. https://doi.org/10.1016/j.envpol. 2011.07.005

Mattila H, Valev D, Havurinne V, Khorobrykh S, Virtanen O, Antinluoma M, Mishra KB, Tyystjärvi E (2018) Degradation of chlorophyll and synthesis of flavonols during autumn senescencethe story told by individual leaves. AoB Plants. https://doi.org/ 10.1093/aobpla/ply028

Matyssek R (1986) Carbon, water and nitrogen relations in evergreen and deciduous conifers. Tree Physiol 2:177-187. https://doi.org/ 10.1093/treephys/2.1-2-3.177

Matyssek R, Karnosky DFF, Wieser G, Percy K, Oksanen E, Grams TE, Kubiske M, Hanke D, Pretzsch H (2010) Advances in understanding ozone impact on forest trees: messages from novel phytotron and free-air fumigation studies. Environ Pollut 158:1990 2006. https://doi.org/10.1016/j.envpol.2009.11.033

Mills G, Sharps K, Simpson D, Pleijel H, Frei M, Burkey K, Emberson L, Uddling J, Broberg M, Feng Z, Kobayashi K, Agrawal M (2018) Closing the global ozone yield gap: quantification and cobenefits for multistress tolerance. Glob Chang Biol 24:48694893. https://doi.org/10.1111/gcb.14381

Moura BB, Hoshika Y, Ribeiro RV, Paoletti E (2018) Exposure- and flux-based assessment of ozone risk to sugarcane plants. Atmos Environ 176:252-260. https://doi.org/10.1016/j.atmosenv.2017. 12.039

Mrak T, Štraus I, Grebenc T, Gričar J, Hoshika Y, Carriero G, Paoletti E, Kraigher H (2019) Different belowground responses to elevated ozone and soil water deficit in three European oak species (Quercus ilex, Q. pubescens and Q. robur). Sci Total Environ 651:1310-1320. https://doi.org/10.1016/j.scitotenv.2018.09.246

Mrak T, Eler K, Badea O, Hoshika Y, Carrari E, Paoletti E, Kraigher H (2020) Elevated ozone prevents acquisition of available nitrogen due to smaller root surface area in poplar. Plant Soil 450:585599. https://doi.org/10.1007/s11104-020-04510-7

Mukherjee A, Singh Yadav D, Agrawal SB, Agrawal M (2021) Ozone a persistent challenge to food security in India: Current status and policy implications. Curr Opin Environ Sci Heal 19:100220. https://doi.org/10.1016/j.coesh.2020.10.008

Ohta T, Hiyama T, Iijima Y, Kotani A, Maximov TC (2019) Watercarbon dynamics in Eastern Siberia. Springer, Singapore

Oksanen E, Pandey V, Pandey AK, Keski-Saari S, Keski-Saari S, Sharma C (2013) Impacts of increasing ozone on Indian plants. Environ Pollut 177:189-200. https://doi.org/10.1016/j.envpol. 2013.02.010

Osawa A, Zyryanova OA, Matsuura Y, Kajimoto T, Wein RW (2010) Permafrost ecosystems-Siberian larch forests. Springer, Dordrecht

Overall JE, Spiegel DK (1969) Concerning least squares analysis of experimental data. Psychol Bull 72:311-322. https://doi.org/10. 1037/h0028109

Owens JN (2008) The Reproductive Biology of Western Larch. Volume 8 of FGC extension note. Inland Empire Tree Improvement Cooperative, 80p. ISBN: 0772658773

Owens JN, Molder M (1979) Sexual reproduction of Larix occidentalis. Can J Bot 57:2673-2690 
Owens JN, Molder M (2011) Bud development in Larix occidentalis. II. Cone differentiation and early development. Can J Bot 57:1557-1572

Pan L, Lie G, Xue L, Chen H (2019) Changes of Cinnamomum camphora root characteristics and soil properties under ozone stress in South China. Environ Sci Pollut Res 26:30684-30692. https:// doi.org/10.1007/s11356-019-05199-7

Pan L, Lin WQ, Yu M, Lie GW, Xue L, Chen HY (2020) Effects of elevated ozone concentrations on root characteristics and soil properties of Elaeocarpus sylvestris and Michelia chapensis. Bull Environ Contam Toxicol 104:682-688. https://doi.org/10.1007/ s00128-020-02832-x

Pandey AK, Majumder B, Keski-Saari S, Kontunen-Soppela S, Pandey V, Oksanen E (2019) High variation in resource allocation strategies among 11 Indian wheat (Triticum aestivum) cultivars growing in high ozone environment. Climate 7:23. https://doi. org/10.3390/cli7020023

Paoletti E, Contran N, Manning W, Ferrara AM (2009) Use of the antiozonant ethylenediurea (EDU) in Italy: verification of the effects of ambient ozone on crop plants and trees and investigation of EDU's mode of action. Environ Pollut 157:1453-1460. https://doi.org/10.1016/j.envpol.2008.09.021

Parsons WFJ, Lindroth RL, Bockheim JG (2004) Decomposition of Betula papyrifera leaf litter under the independent and interactive effects of elevated $\mathrm{CO}_{2}$ and $\mathrm{O}_{3}$. Glob Chang Biol 10:1666-1677. https://doi.org/10.1111/j.1365-2486.2004.00851.x

Parsons WFJ, Bockheim JG, Lindroth RL (2008) Independent, interactive, and species-specific responses of leaf litter decomposition to elevated $\mathrm{CO}_{2}$ and $\mathrm{O}_{3}$ in a northern hardwood forest. Ecosystems 11:505-519. https://doi.org/10.1007/s10021-008-9148-x

Powell GR (1995) Within-crown patterns of shoot development and their relationship to cone production in young tamarack. In: Ecology and management of Larix forests: a look ahead. (eds. WC Smith, KJ McDonald). pp. 387-394. U.S. Dept. of Agriculture, Forest Service, Intermountain Research Station, Ogden, Utah, General Technical Report GTR-INT-319.

Proietti C, Fornasier MF, Sicard P, Anav A, Paoletti E, De Marco A (2020) Trends in tropospheric ozone concentrations and forest impact metrics in Europe over the time period 2000-2014. J For Res 1:3. https://doi.org/10.1007/s11676-020-01226-3

Rathore D, Chaudhary IJ (2019) Ozone risk assessment of castor (Ricinus communis L.) cultivars using open top chamber and ethylenediurea (EDU). Environ Pollut 244:257-269. https://doi.org/10. 1016/j.envpol.2018.10.036

Ryu K, Watanabe M, Shibata H, Takagi K, Nomura M, Koike T (2009) Ecophysiological responses of the larch species in northern Japan to environmental changes as a basis for afforestation. Landsc Ecol Eng 5:99-106. https://doi.org/10.1007/s11355-009-0063-x

Sacchelli S, Carrari E, Paoletti E, Anav A, Hoshika Y, Sicard P, Screpanti A, Chirici G, Cocozza C, De Marco A (2021) Economic impacts of ambient ozone pollution on wood production in Italy. Sci Rep 11:154. https://doi.org/10.1038/s41598-020-80516-6

Saitanis C, Riga-Karandinos A, Karandinos M (2001) Effects of ozone on chlorophyll and quantum yield of tobacco (Nicotiana tabacum L.) varieties. Chemosphere 42:945-953. https://doi.org/10.1016/ S0045-6535(00)00158-2

Sakuraba Y, Yokono M, Akimoto S, Tanaka R, Tanaka A (2010) Deregulated chlorophyll $b$ synthesis reduces the energy transfer rate between photosynthetic pigments and induces photodamage in Arabidopsis thaliana. Plant Cell Physiol 51:1055-1065. https://doi.org/10.1093/pcp/pcq050

Salvatori E, Fusaro L, Manes F (2017) Effects of the antiozonant ethylenediurea (EDU) on Fraxinus ornus L.: the role of drought. Forests 8:320. https://doi.org/10.3390/f8090320

Sayyad-Amin P, Jahansooz MR, Borzoue A, Ajili F (2016) Changes in photosynthetic pigments and chlorophyll- $a$ fluorescence attributes of sweet-forage and grain sorghum cultivars under salt stress. J Biol Phys 42:601-620. https://doi.org/10.1007/ s10867-016-9428-1

Schmincke H-U (2004) Volcanism. Springer-Verlag, Berlin Heidelberg, p 324

Schulze E-D, Beck E, Buchmann N, Clemens S, Müller-Hohenstein K, Scherer-Lorenzen M (2019) Plant ecology. Springer, Berlin

Shang B, Feng Z, Li P, Calatayud V (2018) Elevated ozone affects C, $\mathrm{N}$ and $\mathrm{P}$ ecological stoichiometry and nutrient resorption of two poplar clones. Environ Pollut 234:136-144

Shinano T, Lei TT, Kawamukai T, Inoue MT, Koike T, Tadano T (1996) Dimethylsulfoxide method for the extraction of chlorophylls $a$ and $b$ from the leaves of wheat, field bean, dwarf bamboo, and oak. Photosynthetica 32:409-415

Sicard P, De Marco A, Carrari E, Dalstein-Richier L, Hoshika Y, Badea O, Pitar D, Fares S, Conte A, Popa I, Paoletti E (2020) Epidemiological derivation of flux-based critical levels for visible ozone injury in European forests. J For Res 31:1509-1519. https://doi. org/10.1007/s11676-020-01191-x

Sieber M, Lüscher D (1995) Architecture of European larch with special reference to flowering. In: Ecology and management of Larix forests: a look ahead. (eds. W. C. Smith \& K. J. McDonald). pp. 382-386. U.S. Dept. of Agriculture, Forest Service, Intermountain Research Station, Ogden, Utah, General Technical Report GTR-INT-319.

Singh AA, Singh S, Agrawal M, Agrawal SB (2015) Assessment of ethylene diurea-induced protection in plants against ozone phytotoxicity. Rev Environ Contam Toxicol 233:129-184. https:// doi.org/10.1007/978-3-319-10479-9_4

Singh S, Singh P, Agrawal SB, Agrawal M (2018) Use of ethylenediurea (EDU) in identifying indicator cultivars of Indian clover against ambient ozone. Ecotoxicol Environ Saf 147:1046-1055. https://doi.org/10.1016/j.ecoenv.2017.09.068

Sugai T, Kam D-G, Agathokleous E, Watanabe M, Kita K, Koike $\mathrm{T}$ (2018) Growth and photosynthetic response of two larches exposed to $\mathrm{O}_{3}$ mixing ratios ranging from preindustrial to near future. Photosynthetica 56:901-910. https://doi.org/10.1007/ s11099-017-0747-7

Surabhi S, Gupta SK, Pande V, Pandey V (2020) Individual and combined effects of ethylenediurea (EDU) and elevated carbon dioxide $\left(\mathrm{ECO}_{2}\right)$, on two rice (Oryza sativa $\mathrm{L}$.) cultivars under ambient ozone. Environ Adv 2:100025. https://doi.org/10.1016/j.envadv. 2020.100025

Tisdale RH, Zobel RW, Burkey KO (2021) Tropospheric ozone rapidly decreases root growth by altering carbon metabolism and detoxification capability in growing soybean roots. Sci Total Environ 766:144292. https://doi.org/10.1016/j.scitotenv.2020.144292

Tiwari S (2017) Ethylenediurea as a potential tool in evaluating ozone phytotoxicity: a review study on physiological, biochemical and morphological responses of plants. Environ Sci Pollut Res 24:14019-14039. https://doi.org/10.1007/s11356-017-8859-y

Tiwari S, Agrawal M (2018) Mitigation of ozone stress. In: tropospheric ozone and its impacts on crop plants. Springer, Cham, pp 167-189

Ueno AC, Gundel PE, Omacini M, Ghersa CM, Bush LP, MartínezGhersa MA (2016) Mutualism effectiveness of a fungal endophyte in an annual grass is impaired by ozone. Funct Ecol 30:226-234. https://doi.org/10.1111/1365-2435.12519

Ueno AC, Gundel PE, Ghersa CM, Demkura PV, Card SD, Mace WJ, Martínez-Ghersa MA (2020) Ontogenetic and trans-generational dynamics of a vertically transmitted fungal symbiont in an annual host plant in ozone-polluted settings. Plant Cell Environ 43:2540-2550. https://doi.org/10.1111/pce.13859

Unger N, Zheng Y, Yue X, Harper KL (2020) Mitigation of ozone damage to the world's land ecosystems by source sector. Nat Clim Chang 10:134-137. https://doi.org/10.1038/s41558-019-0678-3 
Usoltsev VA, Koltunova AI, Kajimoto T, Osawa A, Koike T (2002) Geographical gradients of annual biomass production from larch forests in northern Eurasia. Eurasian J For Res 5:55-62

Van Heerwaarden LM, Toet S, Aerts R (2003) Nitrogen and phosphorus resorption efficiency and proficiency in six sub-arctic bog species after 4 years of nitrogen fertilization. J Ecol 91:10601070. https://doi.org/10.1046/j.1365-2745.2003.00828.x

Vitale M, Amitrano W, Hoshika Y, Paoletti E (2019) Plant speciesspecific litter decomposition rates are directly affected by tropospheric ozone: analysis of trends and modelling. Water Air Soil Pollut 230:311. https://doi.org/10.1007/s11270-019-4339-y

Walker AP, Beckerman AP, Gu L, Kattge J, Cernusak LA, Domingues TF, Scales JC, Wohlfahrt G, Wullschleger SD, Woodward FI (2014) The relationship of leaf photosynthetic traits $-V_{\text {cmax }}$ and $J_{\max }$ - to leaf nitrogen, leaf phosphorus, and specific leaf area: a meta-analysis and modeling study. Ecol Evol 4:3218-3235. https://doi.org/10.1002/ece3.1173

Wang X, Agathokleous E, Qu L, Fujita S, Watanabe M, Tamai Y, Mao Q, Koyama A, Koike T (2018) Effects of simulated nitrogen deposition on ectomycorrhizae community structure in hybrid larch and its parents grown in volcanic ash soil: the role of phosphorous. Sci Total Environ 618:905-915. https://doi.org/10.1016/j. scitotenv.2017.08.283

Xin Y, Yuan X, Shang B, Manning WJ, Yang A, Wang Y, Feng Z (2016) Moderate drought did not affect the effectiveness of ethylenediurea (EDU) in protecting Populus cathayana from ambient ozone. Sci Total Environ 569-570:1536-1544. https://doi.org/10. 1016/j.scitotenv.2016.06.247

Xu S, He X, Burkey K, Chen W, Li P, Li Y, Li B, Wang Y (2019) Ethylenediurea (EDU) pretreatment alleviated the adverse effects of elevated $\mathrm{O}_{3}$ on Populus alba "Berolinensis" in an urban area. J Environ Sci 84:42-50. https://doi.org/10.1016/j.jes.2019.04.018
Xu X, Lin W, Xu W, Jin J, Wang Y, Zhang G, Zhang X, Ma Z, Dong Y, Ma Q, Yu D, Li Z, Wang D, Zhao H (2020) Long-term changes of regional ozone in China: implications for human health and ecosystem impacts. Elem Sci Anth 8:13. https://doi.org/10.1525/ elementa.409

Xu Y, Shang B, Peng J, Feng Z, Tarvainen L (2021) Stomatal response drives between-species difference in predicted leaf water-use efficiency under elevated ozone. Environ Pollut 269:116137. https:// doi.org/10.1016/j.envpol.2020.116137

Yue X, Unger N, Harper K, Xia X, Liao H, Zhu T, Xiao J, Feng Z, Li J (2017) Ozone and haze pollution weakens net primary productivity in China. Atmos Chem Phys 17:6073-6089. https://doi.org/ 10.5194/acp-17-6073-2017

Zhang P, Shao G, Zhao G, Le Master DC, Parker GR, Dunning JB Jr, Li Q (2000) China's forest policy for the 21st century. Science 288:2135-2136. https://doi.org/10.1126/science.288.5474.2135

Zhang X, Xu Y, Huang B (2019) Lipidomic reprogramming associated with drought stress priming-enhanced heat tolerance in tall fescue (Festuca arundinacea). Plant Cell Environ 42:947-958. https://doi.org/10.1111/pce.13405

Ziauka J, Kuusienë S (2006) Changes in development of European larch (Larix decidua Mill.) vegetative buds induced by plant hormones. Baltic For 12:141150

Publisher's Note Springer Nature remains neutral with regard to jurisdictional claims in published maps and institutional affiliations. 